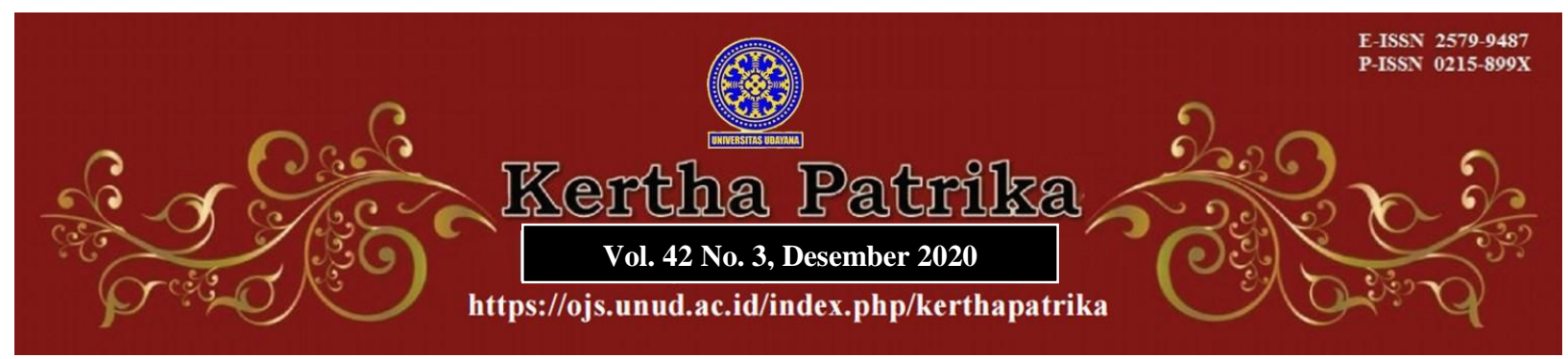

\title{
Sistem Pemulihan Kerugian Integratif Bagi Korban Penipuan Skala Masif di Indonesia
}

\author{
Peter Jeremiah Setiawan ${ }^{1}$
}

${ }^{1}$ Fakultas Hukum Universitas Surabaya, E-mail: peterjsetiawan@staff.ubaya.ac.id

\begin{tabular}{l}
\hline Info Artikel \\
\hline Masuk: 25 Juni 2020 \\
Diterima: 29 Desember 2020 \\
Terbit: 31 Desember 2020 \\
Keywords : \\
Massive Fraud; Victim Loss \\
Recovery; Victim Restitution \\
Kata kunci: \\
Penipuan Masif; Pemulihan \\
Kerugian Korban; Restitusi \\
\end{tabular}

\begin{abstract}
In several cases, fraud as a financial crime has developed into a massive scale crime in Indonesia. This article presents a study regarding the abovementioned massive scale fraud cases that is conducted by normative juridical method with a statutory, case, and conceptual approaches. The study begins by examining primary and secondary legal materials, both Indonesian law and regulations, court decisions, and related legal literature. Analysis and interpretation are carried out aimed at identifying the characteristics of massive scale fraud cases along with the problems faced by the victims, and finally formulate a prescription regarding the loss recovery system for the victims. The results of the study show that massive fraud in Indonesia is characterized primarily by the initial business relationship that was formed previously between the perpetrator and the victim. In this relation, criminals undertake large fund-raising activities from the society using ponzi or money game scheme accompanied by unprofessional and non-transparent corporate financial management. Problems arise in efforts to recover victim's losses, mainly due to the complexity and overlapping of the legal provisions of loss recovery and their legal implications. To solve this problem, a system can be formulated by integrating features in civil and criminal procedural laws, bankruptcy procedures, and restitution system, which can support the fair settlement for victims. This stage consists of the drafting of restitution application involving Witness and Victim Protection Agency, an examination of restitution in court proceedings along with examining the perpetrator's deed and criminal intent, followed by the victim's restitution crimes as punishment and assets confiscation. Finally, the settlement of the assets of the perpetrators and payment of victim losses.
\end{abstract}

\begin{tabular}{l}
\hline Abstrak \\
\hline Penipuan sebagai kejahatan keuangan dalam beberapa \\
kasus berkembang menjadi kejahatan skala masif di \\
Indonesia. Artikel ini menyajikan kajian terhadap kasus- \\
kasus penipuan yang masif tersebut yang dilakukan \\
berdasarkan metode yuridis normatif dengan pendekatan
\end{tabular}




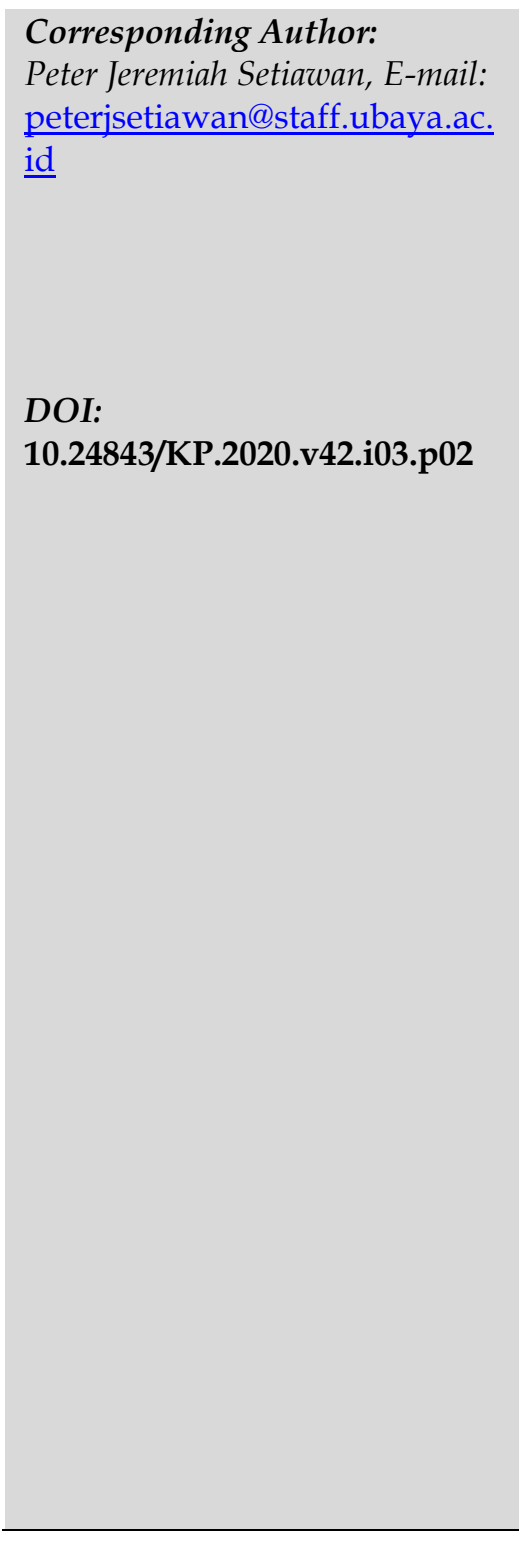

\begin{abstract}
kasus, perundang-undangan, dan konseptual. Kajian dimulai dengan mempelajari bahan hukum primer dan sekunder, baik berupa peraturan perundang-undangan, putusan pengadilan serta literatur hukum terkait. Selanjutnya dilakukan analisis dan interpretasi yang bertujuan mengidentifikasi karakteristik kasus-kasus penipuan berskala massif, berikut problematika yang dihadapi para korban, serta terakhir merumuskan preskripsi mengenai sistem pemulihan kerugian bagi para korban tersebut. Hasil kajian menunjukkan penipuan masif di Indonesia berkarakteristik pokok pada hubungan awal keperdataan (bisnis) yang dibentuk sebelumnya antara pelaku dan korban. Pada hubungan tersebut, pelaku kejahatan melakukan kegiatan penghimpunan dana yang besar dari masyarakat dengan modus skema ponzi atau money game yang disertai dengan pengelolaan keuangan korporasi yang tidak profesional dan transparan. Problematika timbul pada upaya pemulihan kerugian para korban, utamanya karena kompleksitas dan tumpang tindihnya ketentuan pemulihan kerugian beserta implikasi hukumnya. Untuk menyelesaikan problematika ini, maka dapat dirumuskan suatu konsep sistem integratif dengan memadukan fitur-fitur pada hukum acara perdata dan pidana, prosedur kepailitan, dan sistem restitusi korban, yang mampu mendukung dan memperkuat penyelesaian pemulihan kerugian yang adil bagi korban. Tahapan sistem ini secara teknis terdiri atas penyusun permohonan restitusi yang melibatkan Lembaga Perlindungan Saksi dan Korban, pemeriksaan restitusi pada sidang pengadilan bersama dengan pemeriksaan perbuatan dan kesalahan pelaku kejahatan, dilanjutkan dengan penjatuhan pemidanaan restitusi serta perampasan aset. Terakhir, pemberesan harta kekayaan pelaku dan pembayaran kerugian sebagai pemulihan korban.
\end{abstract}

\title{
1. Pendahuluan
}

Penipuan atau perbuatan curang sebagai kejahatan keuangan telah berkembang dalam beragam modus, mulai dari yang skalanya sederhana hingga kompleks yang bahkan melibatkan pelaku terorganisir atau korporasi. Pada tataran konsep hukum, perbuatan curang atau penipuan merupakan perbuatan satu pihak untuk mengelabui atau mengambil keuntungan yang tidak wajar (tidak adil) dari pihak lain. ${ }^{1}$ Hal ini berarti, kejahatan penipuan pasti menyerang kepentingan atas harta kekayaan atau sesuatu hak milik orang lain. Konkretnya, kejahatan ini berpokok pada perbuatan-perbuatan penyiasatan atas kebenaran atau menggunakan tipu muslihat (kebohongan, pemalsuan, tipu daya) untuk memperoleh keuntungan atau hak-hak yang secara hukum milik orang lain. Penipuan umumnya meliputi penyalahgunaan kepercayaan, termasuk pelanggaran atas tugas dan tanggung jawab suatu pihak serta penyimpangan atas

\footnotetext{
${ }^{1}$ Kovacich, G.L. (2008). Fighting Fraud: How to Establish and Manage an Anti-Fraud Program. London: Elsevier Academic Press, h. 30-31.
} 
aktivitas sah yang sebenarnya. ${ }^{2}$ Perbuatan penipuan tidak hanya menyangkut persoalan pidana saja, tetapi secara nyata juga berkorelasi positif dengan hubungan-hubungan hukum keperdataan yang terjadi antara pihak pelaku dan pihak korban. Kejahatan penipuan seringkali didahului dengan hubungan keperdataan dalam berbagai bentuk kepentingan, seperti hubungan perjanjian atau kontrak untuk kepentingan bisnis atau hubungan kerja dalam korporasi. Adanya karakter hubungan bisnis atau hubungan kerja pada pelaku ini yang menegaskan penipuan sebagai white collar crime, sebab para pelakunya memiliki kedudukan, kemampuan atau pengetahuan profesional tertentu. ${ }^{3}$

Pada tataran praktis, kejahatan penipuan sudah dianggap sebagai "penyakit" utama yang selalu mengancam hubungan bisnis atau korporasi serta memberikan dampak kerugian paling nyata, tidak hanya bagi pihak pelaku usaha (korporasi) saja namun juga bagi pihak konsumen atau nasabah. Dua pihak dalam hubungan bisnis ini sama-sama memiliki kemungkinan untuk saling mencurangi serta merugikan satu sama lain. Akan tetapi, problematika lebih serius akan muncul jika yang melakukan penipuan adalah pihak pelaku usaha atau pemiliki korporasi yang bertanggungjawab atas hubungan bisnis dengan sejumlah besar nasabah/ konsumen dan aset-aset yang dimiliki nasabah/ konsumen. Dalam hal ini penipuan skala masif dapat terjadi. Istilah masif dalam penipuan yang dimaksud merujuk pada jumlah korban yang mencapai ratusan hingga ribuan serta jumlah kerugian yang diderita korban yang mencapai ratusan milyar hingga trilyun rupiah. Kajian komparasi tentang kasus-kasus penipuan di negaranegara berbagai belahan dunia, termasuk Indonesia menunjukkan bukti konkret bahwa penipuan skala masif telah menjadi persoalan sejak lama.

Di Jepang misalnya, kasus penipuan skala masif pernah tebongkar pada tahun 2009. Penipuan ini dilakukan oleh Kazutsugi Nami dengan menggunakan modus investasi uang virtual bernama Enten pada perusahaan miliknya. Penipuan ini mengakibatkan 37.000 korban dengan kerugian mencapai 126 milyar yen atau setara dengan 1,4 milyar USD. 4 Di Amerika Serikat, salah satu kasus penipuan dalam skala paling masif terbongkar pada tahun 2008. Penipuan ini dilakukan oleh Bernard Madoff dan kronikroninya melalui perusahaan pengelolaan efek dengan menggunakan skema ponzi. Kasus ini mengakibatkan kerugian bagi ribuan korban yang menjadi klien perusahaan Bernad Madoff dengan estimasi nilai kerugian mencapai 65 milyar USD. Kasus penipuan skala masif lainnya terbongkar pada tahun 2018. Arthur Lamar Adams sebagai pemilik suatu perusahaan pengelolaan kayu timber melakukan penipuan investasi juga dengan skema ponzi, mengakibatkan korban berjumlah ratusan dengan estimasi uang investasi yang mencapai 164,5 milyar USD serta nilai kerugian mencapai

\footnotetext{
2 Picket, K.H.S., \& Picket, J. (2002). Financial Crime Investigation and Control. New York: John Wiley and Sons, Inc, h. 3.

${ }^{3}$ Ibid., h. 1-2.

${ }^{4}$ The Guardian. Arrests Made in What Could Be Biggest Investment Scam in Japanese History. Available from https://www.theguardian.com/business/2009/feb/05/japan-kazutsugi-nami-ladiesgentlemen. (Diakses 10 November 2019).

World Finance. 10 of the Most Controversial Financial Fraudsters. Available from https://www.worldfinance.com/ strategy/legal-management/ 10-of-the-most-controversial-financialfraudsters. (Diakses 10 November 2019).
} 
85 milyar USD. ${ }^{5}$ Di Indonesia kasus-kasus penipuan skala masif yang terjadi juga tidak sedikit, seperti misalnya kasus penipuan investasi oleh koperasi Cipaganti dan Pandawa Mandiri Group. Atau kasus lainnya yakni penggelapan dana nasabah oleh perusahaan biro perjalanan haji dan umrah seperti First Travel, Abu Tours dan PT. SBL. Masingmasing kasus tersebut melibatkan ratusan hingga ribuan korban dan estimasi kerugian mencapai milyaran hingga trilyunan rupiah. ${ }^{6}$

Pada konteks penipuan sebagai kejahatan terhadap harta kekayaan seperti yang telah diuraikan di atas, maka kerugian korban pasti bersifat materiil yang secara matematis nilai kerugian ini dapat dihitung nilainya. Dalam sistem peradilan pidana yang berorientasi pada perlindungan hak-hak korban, maka korban berhak atas pemulihan atas kerugian-kerugian materiil tersebut. Pengaturan hak tersebut tidak hanya meliputi abstraksi ketentuan haknya saja, melainkan yang terpenting adalah perlindungan negara atas upaya hukum dan sistem pemulihan hak-hak korban tersebut. Perlindungan hak-hak korban yang demikian telah dirumuskan sejak lama oleh para pakar serta diwujudkan dalam konsep tentang restitusi dan kompensasi bagi korban. Pada Deklarasi PBB tentang Basic Principles of Justice for Victims of Crime and The Abuse of Power, restitusi dan kompensasi menjadi aturan standar minimum yang yang harus dimiliki negara untuk melindungi kepentingan-kepentingan korban, disamping ketentuanketentuan seperti akes keadilan, perlakuan yang adil serta tindakan bantuan lainnya bagi korban. Restitusi dan kompensasi pada dasarnya sama-sama merupakan bentuk pemulihan atas kerugian atau beban-beban yang diderita korban akibat kejahatan yang terjadi ${ }^{7}$, hanya saja dalam restitusi, tindakan pemulihan dilakukan oleh pelaku kejahatan atau pihak ketiga sedangkan kompensasi dilakukan oleh negara didasarkan pada pertimbangan-pertimbangan tertentu.

Problematika korban penipuan di Indonesia sebenarnya tidak pernah lepas dari fokus kajian beberapa penulis atau peneliti hukum. Terkait dengan fokus kajian artikel ini, publikasi atau penelitian terdahulu menujukkan persoalan penipuan lebih banyak dianalisis dari perspertif perlindungan investasi seperti kajian yang dilakukan $\mathrm{N}$. Mantulangi, berjudul "Kajian Hukum Investasi dan Perlindungan terhadap Korban

\footnotetext{
${ }^{5}$ Forbes. Roger Aitken. After U.S. SEC Shuts Down \$85M Ponzi Scheme, Can They Ever Be Eradicated? Available from https://www.forbes.com/sites/rogeraitken/2018/05/04/after-u-s-sec-shutsdown-85m-ponzi-scheme-can-they-ever-be-eradicated/\#355debf057fa. (Diakses 12 November 2019). Jackson Free Press. Lamar Adams Sentenced to 20 Years in Probable Largest Ponzi Scheme in State History. Available from: http://www.jacksonfreepress.com/ news/2018/oct/30/lamar-adamssentenced-20-years-probable-largest-po/. (Diakses 11 November 2019).

U.S. Securities and Exchange Commission. Principal of Mississippi Company Who Ran Multimillion Dollar Ponzi Scheme Sentenced to 19.5 Years Imprisonment in Parallel Criminal Action. Available from $\mathrm{https}$ ://www.sec.gov/litigation/litreleases/2018/lr24347.htm. (Diakses 10 November 2019).

${ }^{6}$ Detik. Trio Penipu Calon Tamu Allah Abu Tours PT SBL First Travel. Available from https://hews.detik.com/berita/d-3935516/trio-penipu-calon-tamu-allah-abu-tours-pt-sbl-first-travel/1. (Diakses 12 November 2019).

Detik Finance. Ini 12 Koperasi Abal-Abal Yang Bikin Buntung. Available from, https://finance.detik.com/moneter/d-4329974/ini-12-koperasi-abal-abal-yang-bikin-buntung. (Diakses 11 November 2019).

7 Boland, M.L. (2008). Crime Victim's Guide to Justice. Nappervile: Sphinx Publishing, h. 9-10, 8788.
} 
Investasi Bodong" 8 atau yang ditulis oleh A. A. A. Primantari dan K. Sarna berjudul "Upaya Menanggulangi Investasi Bodong di Internet." 9 Beberapa kajian penipuan seringpula fokus pada studi kasus penipuan dengan locus delicti yang spesifik seperti di daerah, kota atau kabupaten tertentu di Indonesia, seperti yang ditulis ole H.P. Pamungkas berjudul "Analisis Kriminologis terhadap Kejahatan Penipuan dengan Modus Penggandaan Uang (Studi Kasus di Polresta Bandar Lampung)"10 atau kajian oleh M. Surahmi berjudul "Perlindungan Hukum bagi Korban Penipuan Investasi (Studi Kasus di Kota Palembang"11 serta kajian oleh A. H. Samudra berjudul "Modus Operandi dan Problematika Penanggulangan Tindak Pidana Penipuan Daring" yang menggunakan basis data kasus penipuan di Jawa Timur. ${ }^{12}$ Berdasarkan publikasi atau penelitian terdahulu tersebut, maka kajian pada artike ini memuat temuan yang baru dan berbeda, khususnya dalam hal mengkonstantir karakteristik beberapa kejahatan penipuan skala masif di Indonesia serta persoalan-persoalan yang secara spesifik dihadapi korban dalam memulihkan kerugiannya. Temuan tersebut dilanjutkan dengan merumuskan solusi sistem pemulihan kerugian integratif atas kerugian korban tersebut.

Jika menelaah ketentuan hukum positif Indonesia, terdapat beragam upaya hukum yang dapat ditempuh korban untuk memperoleh ganti kerugiannya baik secara langsung maupun tidak langsung, mulai dari upaya permohonan penggabungan gugatan ganti kerugian dengan perkara pidana sesuai Pasal 98-101 Undang-Undang Nomor 8 Tahun 1981 tentang Kitab Undang-Undang Hukum Acara Pidana (selanjutnya disebut KUHAP), upaya gugatan perbuatan melawan hukum berdasarkan Burgerlijk Wetboek/Kitab Undang-Undang Hukum Perdata (selanjutnya disebut BW), upaya permohonan kepailitan menurut Undang-Undang Nomor 37 Tahun 2004 tentang Kepailitan dan Penundaan Kewajiban Pembayaran Utang (selanjutnya disebut UU Kepailitan), hingga upaya permohonan restitusi kepada pengadilan melalui Lembaga Perlindungan Saksi dan Korban (selanjutnya disebut LPSK) berdasarkan Undang-Undang No. 13 Tahun 2006 tentang Perlindungan Saksi dan Korban jo. Undang-Undang No. 31 Tahun 2014 tentang Perubahan atas Undang-Undang Nomor 13 Tahun 2006 (selanjutnya disebut UU Perlindung Saksi dan Korban). Masing-masing upaya tersebut memiliki hukum acara dan akibat atau konsekuensi hukum yang berbeda-beda pula. Setiap korban atau kelompok-kelomok korban penipuan yang demikian banyak, dapat menempuh upaya-upaya hukum sesuai pertimbangannya masing-masing. Keadaan ini dapat menimbulkan ekses-ekses negatif berikutnya bagi korban, yang pada gilirankan justru mendegradasi atau bahkan menghilangkan hak

8 Mantulangi, N. (2017). Kajian Hukum Investasi dan Perlindungan terhadap Korban Investasi Bodong. Lex Administratum, 5(1):108-115, h. 113-114.

9 Primantasari, A.A.A., \& Sarna, K. (2014). Upaya Menanggulangi Investasi Bodong. Kertha Semaya, 2(3): 108-115, h 113-114.

10 Pamungkas, H.P. (2017). Analisis Kriminologis terhadap Kejahatan Penipuan dengan Modus Penggandaan Uang (Studi Kasus di Polresta Bandar Lampung). Poenale: Jurnal Bagian Hukum Pidana, 5(16).

11 Surahmi, M. (2019). Perlindungan Hukum bagi Korban Penipuan Investasi (Studi Kasus di Kota Palembang). Jurnal Thengkyang 2(1):85-104, h. 85.

12 Samudra, A. H., (2019) Modus Operandi Dan Problematika Penanggulangan Tindak Pidana Penipuan Daring. Mimbar Hukum, 31(1): 59-74, DOI: https://doi.org/10.22146/jmh.34786, h. 62-63. 
korban-koban atas pemulihan kerugiannya. ${ }^{13}$ Persoalan sistemik ini jelas memerlukan analisis yang berorietasi pada solusi, didasarkan pada kajian-kajian terdahulu yang telah menegaskan bahwa sistem peradilan seharusnya tidak boleh melahirkan viktimasasi sekunder (proses penderitan berikutnya), termasuk melahirkan bebanbeban keuangan (financial burden) berikutnya secara tidak adil kepada korban. ${ }^{14}$ Oleh karena itu, kajian pada penulisan ini bertujuan untuk merumuskan suatu sistem pemulihan kerugian korban yang mampu secara merata dan integratif mengakomodir kepentingan-kepentingan serta menyelesaikan problematika korban-korban penipuan skala masif. Sebelum sistem tersebut dapat dirumuskan, maka penting untuk diidentifikasi terlebih dahulu kasus-kasus kejahatan penipuan skala masif yang terjadi di Indonesia berserta karakteristiknya. Identifikasi kasus beserta karakteristiknya ini menjadi dasar untuk memulai alur pemahaman terhadap problematika korban. Bertolak dari uraian latar belakang di atas, maka dapat ditarik 2 rumusan masalah sebagai berikut:

1. Bagaimanakah karakteristik dari kasus-kasus penipuan berskala masif yang ada di Indonesia?

2. Bagaimanakah sistem pemulihan integratif atas kerugian korban kejahatan penipuan skala masif?

\section{Metode Penelitian}

Artikel ini menggunakan jenis penelitian yuridis normatif berdasarkan pendekatan kasus, pendekatan perundang-undangan, dan pendekatan konseptual. Kajian dimulai dengan menginventarisasi, mengklasifikasi serta melakukan sistematisasi terhadap bahan-bahan hukum primer maupun sekunder yang memiliki relevansi dan mampu menjawab rumusan permasalahan. Bahan hukum primer terdiri dari peraturan perundang-undangan serta putusan pengadilan. Peraturan yang digunakan di antaranya KUHAP, BW, UU Kepailitan serta UU Perlindungan Saksi dan Korban, sedangkan putusan-putusan pengadilan yang digunakan adalah putusan peradilan pidana, baik tingkat pertama, banding serta kasasi yang berkaitan dengan kasus-kasus penipuan tertentu. Terkait bahan hukum sekunder meliputi literatur hukum yang memuat penjelasan peraturan-perundangan, prinsip-prinsip serta doktrin-doktrin hukum yang berkembang terkait penipuan, korban kejahatan, serta pemulihan kerugian

13 Dignan, J. (2005). Understanding Victims and Restorative Justice. New York: Open University Press, h. 23, 30-31.

14 Gravin, M., \& Clair, S.L. (2013). Ensuring Full Restitution for Crime Victims: Polyvictims as a Case Study in Overcoming Causation Challenges. Victim Law Bulletin, National Crime Victim Law Institute, July (2013):1-10, h. 4.

Martin, K.D., Smith, S.S., \& Still, W (2017). Shackled to Debt: Criminal Justice Financial Obligations and the Barriers to Re-Entry They Create. New Thinking in Comunity Correction, January 2017 (4):1-26, h. 13.

Button, M., Lewis, C., \& Tapley J. (2014). Not a Victimless Crime: The Impact of Fraud on Individual Victims and Their Families. Security Journal, 27 (1), 36-54, DOI: https://doi.org/10.1057/sj.2012.11, h. 51-53.

Brenner, L., Meyll, T., Stolper, O., \& Walter, A. (2020). Consumer Fraud Victimization and Financial Well-being. Journal of Economic Psychology, 76 (C), DOI: https://doi.org/10.1016/i.joep.2019.102243, h. 25-26. 
atau resitusi korban kejahatan. Selanjutnya untuk analisis, yang pertama dilakukan penelaahan terhadap bahan-bahan hukum khususnya terhadap putusan-putusan pengadilan atau bahan terkait deskripsi kasus untuk mengkonstantir karakteristik dari kasus-kasus penipuan berskala masif di Indonesia. Analisis dilanjutkan dengan mengkaji problematika normatif yang dihadapi para korban penipuan skala masif tersebut dengan basis metode deduksi. Analisis kemudian diakhiri dengan merumuskan preskripsi mengenai sistem pemulihan kerugian bagi korban penpuan skala masif yang seyogianya dilakukan dan dapat diterapkan di Indonesia.

\section{Hasil dan Pembahasan}

\subsection{Identifikasi Kasus Penipuan Masif di Indonesia dan Karakteristiknya}

Sebelum sistem pemulihan kerugian korban penipuan masif dikonstruksikan dalam kajian ini, maka penting untuk diidentifikasi terlebih dahulu contoh konkret kasus kejahatan penipuan dengan skala masif yang terjadi di Indonesia, juga karakteristik yang muncul dan problematika korban pada kasus-kasus kejahatan tersebut. Kajian terhadap kasus, karakteristik dan problematika korban tersebut dapat dijadikan ratio legis dalam merumuskan suatu sistem pemulihan kerugian bagi korban penipuan skala masif. Identifikasi kasus penipuan skala masif ini akan difokuskan pada komponenkomponen penjelasan tentang pelaku dan korban, locus delicti, tempus delicti, modus, serta kerugian materiil yang dialami korban. Identifikasi beberapa kasus-kasus penipuan skala masif yang terjadi di Indonesia tersebut dapat diuraikan dalam penjelasan tabel sebagai berikut:

Tabel 1. Modus dan Kerugian Korban Penipuan Skala Masif di Indonesia

\begin{tabular}{|c|c|c|c|}
\hline No & Kasus & Modus & $\begin{array}{l}\text { Jumlah Korban dan } \\
\text { Kerugian }\end{array}$ \\
\hline 1 & $\begin{array}{l}\text { Kasus } \\
\text { Koperasi } \\
\text { Cipaganti } \\
(2007-2014)^{15}\end{array}$ & $\begin{array}{l}\text { - Menghimpunan dana dari nasabah } \\
\text { dengan cara pembentukan skema } \\
\text { kerjasama penyertaan modal dan } \\
\text { pengelolaan kegiatan usaha koperasi } \\
\text { dengan janji pengembalian keuntungan } \\
\text { serta modal yang tinggi serta tanggung } \\
\text { jawab atas kerugian kegiatan usaha. } \\
\text { - Mencari nasabah dengan pemasaran } \\
\text { berjenjang (multi level marketing system), } \\
\text { yakni pemberian komisi bagi nasabah } \\
\text { yang mampu merekrut nasabah baru. } \\
\text { - Mengalihkan atau menggunakan dana- } \\
\text { dana nasabah untuk berbagai kegiatan } \\
\text { usaha lain serta kepentingan pribadi } \\
\text { para pelaku. } \\
\text { - Tetap menghimpun dana tanpa } \\
\text { memberikan informasi tentang kesulitan } \\
\text { keuangan koperasi. }\end{array}$ & $\begin{array}{l}\text { - Korban berjumlah } 8.738 \\
\text { orang } \\
\text { - Estimasi kerugian } 3,2 \\
\text { trilyun rupiah. }\end{array}$ \\
\hline
\end{tabular}

15 Putusan Pengadilan Negeri Bandung Nomor: 198/Pid.B/2015/PN. Bdg.,.Putusan Pengadilan Tinggi Bandung Nomor: 238/PID.SUS/ 2015/PT.Bdg., Putusan Mahkamah Agung Republik Indonesia Nomor: 173 K/Pid.Sus/2016. 


\begin{tabular}{|c|c|c|c|}
\hline & & $\begin{array}{l}\text { - Tidak ada laporan keuangan } \\
\text { (pemasukan) atas hasil usaha koperasi } \\
\text { seperti dalam perjanjian atau } \\
\text { penawaran. }\end{array}$ & \\
\hline 2 & $\begin{array}{l}\text { Kasus GTI } \\
\text { Syariah } \\
(2011-2013)^{16}\end{array}$ & $\begin{array}{l}\text { - Menghimpun dana nasabah dengan cara } \\
\text { membuat skema investasi emas beserta } \\
\text { janji keuntungan tinggi serta } \\
\text { pengembalian uang investasi di akhir } \\
\text { periode. Skema yang berkembang di } \\
\text { perusahaan menjadi skema ponzi atau } \\
\text { money game. } \\
\text { - Mencari nasabah dengan pemasaran } \\
\text { berjenjang (multi level marketing system). } \\
\text { - Mempromosikan kegiatan usaha } \\
\text { berbasis syariah dengan sertifikasi halal } \\
\text { dari MUI dan dukungan dari tokoh- } \\
\text { tokoh politik. } \\
\text { - Pendiri korporasi membawa lari uang } \\
\text { hasil investasi ke luar negeri. }\end{array}$ & $\begin{array}{l}\text { - Korban berjumlah } \\
\text { ribuan. } \\
\text { - Estimasi kerugian } 10 \\
\text { trilyun rupiah }\end{array}$ \\
\hline 3 & $\begin{array}{l}\text { Kasus First } \\
\text { Travel } \\
(2015-2017)^{17}\end{array}$ & $\begin{array}{l}\text { - Menjual jasa perjalanan ibadah umrah } \\
\text { dengan harga yang sangat murah di } \\
\text { bawah standar ketetapan pemerintah, } \\
\text { namun tidak memberangkat orang- } \\
\text { orang yang sudah membayarkan biaya } \\
\text { jasa. } \\
\text { - Membentuk jaringan agen di beberapa } \\
\text { ota dan menggunakan jasa promosi } \\
\text { artis. } \\
\text { - Menghimpun dana dari nasabah yang } \\
\text { satu untuk membiayai pengeluaran } \\
\text { nasabah yang lain. } \\
\text { - Mengalihkan dana-dana nasabah untuk } \\
\text { kepentingan pribadi pelaku, termasuk } \\
\text { pembelian aset-aset pribadi. }\end{array}$ & $\begin{array}{l}\text { - Korban berjumlah } \\
63.310 \text { orang. } \\
\text { - Estimasi kerugian } 905,3 \\
\text { milyar rupiah. }\end{array}$ \\
\hline 4 & $\begin{array}{l}\text { Kasus } \\
\text { Koperasi } \\
\text { Pandawa } \\
(2011-2016)^{18}\end{array}$ & $\begin{array}{l}\text { - Menghimpun dana nasabah dengan cara } \\
\text { membuat skema investasi dengan } \\
\text { keuntungan yang tinggi untuk } \\
\text { penyaluran kredit mikro bagi para } \\
\text { pedagang. Skema yang berkembang di }\end{array}$ & $\begin{array}{l}\text { - Korban diperkirakan } \\
\text { mencapai } 39.068 \text { orang } \\
\text { - Estimasi kerugian } 3,32 \\
\text { trilyun rupiah. }\end{array}$ \\
\hline
\end{tabular}

16 Gatra. Tipu-Tipu Investasi Emas Berkedok Syariah. Available from https://www.gatra.com/detail/news/25595-tipu-tipuinvestasi-emas-berkedok-syariah/. (Diakses 12 November 2019).

Liputan 6. Fakta Menggelitik Dari Penipuan Investasi Emas GTI Syariah. Available from https://www.liputan6.com/ bisnis/read/527856/fakta-menggelitik-dari-penipuan-investasi-emas-gtisyariah. (Diakses 11 November 2019).

17 Putusan Pengadilan Negeri Depok No. 83/Pid.B/2018/PN. Dpk., Putusan Pengadilan Negeri Depok No. 84/Pid.B/2018/PN. Dpk., Putusan Pengadilan Tinggi Bandung No.195/Pid/2018/PT. Bdg., Putusan Mahkamah Agung Indonesia No. 3096 K/Pid.Sus/2018., Putusan Mahkamah Agung Indonesia No. 3095 K/Pid.Sus/2018.

18 Putusan Pengadilan Negeri Depok No. 424/Pid.Sus/2017/PN.Dpk, Putusan Pengadilan Tinggi Bandung No. 37/Pid.Sus/2018/PTBdg, Putusan Mahkamah Agung Republik Indonesia No: 1208 K/Pid.Sus/2018. 


\begin{tabular}{|c|c|c|c|}
\hline & & $\begin{array}{l}\text { perusahaan menjadi skema ponzi atau } \\
\text { money game } \\
\text { - Mencari nasabah dengan pemasaran } \\
\text { berjenjang (multi level marketing system). } \\
\text { Adanya pemberian komisi yang cukup } \\
\text { besar bagi para pimpinan grup nasabah. } \\
\text { - Mengalihkan dana-dana nasabah untuk } \\
\text { kepentingan pribadi pelaku, termasuk } \\
\text { pembelian tanah, rumah dan barang- } \\
\text { barang berhaga lainnya. }\end{array}$ & \\
\hline 5 & $\begin{array}{l}\text { Kasus Abu } \\
\text { Tour } \\
(2012-2018)^{19}\end{array}$ & $\begin{array}{l}\text { - Menjual jasa perjalanan ibadah umrah } \\
\text { dengan harga yang sangat murah di } \\
\text { bawah standar ketetapan pemerintah, } \\
\text { namun tidak memberangkat orang- } \\
\text { orang yang sudah membayarkan biaya } \\
\text { jasa. } \\
\text { - Membentuk jaringan agen di beberapa } \\
\text { kota, dan menawarkan berbagai komisi } \\
\text { dan bonus untuk para agen yang } \\
\text { berhasil mendapatkan nasabah. } \\
\text { - Mengalihkan dana-dana nasabah untuk } \\
\text { kepentingan pribadi pelaku, termasuk } \\
\text { pembelian tanah, rumah dan biaya- } \\
\text { biaya hidup yang mewah. }\end{array}$ & $\begin{array}{l}\text { - Korban diperkirakan } \\
\text { mencapai } 86.720 \text { orang } \\
\text { - Estimasi kerugian 1,2 } \\
\text { trilyun rupiah. }\end{array}$ \\
\hline
\end{tabular}

Memperhatikan deksripsi kasus dalam tabel di atas, maka dapat diketahui karakteristik daripada kasus-kasus penipuan berskala massif di Indonesia sebagai berikut: Pertama, berdimensi kejahatan korporasi. Sebelum benar-benar mewujudkan kehendak jahatnya, para pelaku mendirikan suatu korporasi, termasuk korporasi cabang untuk menjalankan suatu kegiatan usaha. Korporasi ini bahkan berbentuk badan hukum yang didirikan sah sesuai ketentuan peraturan perundang-undangan di Indonesia. Pada kasus-kasus yang telah diidentifikasi, bentuk korporasi yang digunakan adalah perseroan terbatas dan koperasi. Oleh karena itu, kasus-kasus penipuan skala masif memiliki dimensi kejahatan korporasi. Jika merujuk, pada 3 model kejahatan korporasi, kejahatan yang dilakukan tersebut merupakan kejahatan yang dilakukan untuk korporasi (crimes for corporation). ${ }^{20}$ Dalam hal ini, kehendak jahat yang muncul bisa jadi bias, antara bermaksud mendirikan korporasi yang sah untuk melakukan kejahatan atau mendirikan korporasi yang sah terlebih dahulu dan baru kemudian muncul kehendak jahat saat menjalankan kegiatan usaha. Pada kasus-kasus tersebut, kehendak yang jahat yang nampak jelas adalah untuk melindungi kepentingan operasional korporasi, melindungi kepentingan pribadi pemilik korporasi atau utamanya untuk memperoleh keuntungan sebesar-besarnya bagi korporasi dan pemilik korporasi dengan cara curang.

Kedua, pelaku adalah para pendiri atau pengendali korporasi. Sebagaiman telah dijelaskan sebelumnya bahwa kejahatan penipuan skala masif memiliki dimensi sebagai kejahatan korporasi. Oleh karena itu, orang-orang yang berada di balik pendirian dan

19 Putusan Pengadilan Negeri Makasar No. 1235/Pid.B/2018/PN Mks.

20 Box, S. (1983). Power, Crime, and Mystification. New York: Tavistock Publication, h. 18-19. 
pengendalian termasuk pengurusan kegiatan usaha korporasi memiliki peran besar atas rangkaian kejahatan penipuan tersebut. Pada kasus-kasus tersebut, para pendiri korporasi juga menjadi pengurus korporasi, seperti pemegang saham perseroan juga menjabat sebagai direktur perseroan. Para pengendali korporasi ini bahkan memiliki hubungan kekerabatan satu sama lain seperti saudara, hingga hubungan suami-istri.

Ketiga, adanya hubungan keperdataan yang dibentuk antara pelaku dan korban. Setelah pendirian korporasi dilakukan dan berbagai penawaran dilakukan, maka para pelaku merancang dan membangun skema hubungan keperdataan terlebih dahulu dengan para korban. Pada kasus-kasus tersebut, pelaku dan korban menjalin perikatan dalam bentuk perjanjian dengan tujuan sebenarnya untuk saling menguntungkan (hubungan bisnis). Bentuk dan klausul perjanjian ini beragam dan dituangkan dalam suatu akta, mulai dari perjanjian mitra kerjasama, penanaman modal (investasi), hingga secara khusus berupa perjanjian penyelenggaran ibadah umrah bagi umat Muslim.

Keempat, adanya kegiatan penghimpunan atau penarikan sejumlah besar dana dari masyarakat yang berkembang dengan modus skema ponzi atau money game. Modus ini memiliki ciri utama di antaranya, pembayaran keuntungan nasabah (investor) lama dengan menggunakan uang investasi nasabah baru, adanya penawaran yang memuat janji-janji keuntungan yang besar dan cenderung tidak rasional karena tidak didasarkan pada model bisnis yang tidak jelas dan tidak terdaftar resmi. ${ }^{21}$ Modus ini tentu sangat membutuhkan aliran dana yang konsisten dari nasabah atau investor baru, oleh karena itu kegiatan usaha dan penawaran ini kemudian didukung dengan berbagai teknik pemasaran, mulai dari pembentukan jaringan pemasaran (seperti skema multi level marketing), pendirian kantor cabang, perekrutan agen pemasaran, mengadakan promosi yang besar atau bahkan bekerjasama dengan pihak-pihak yang memiliki reputasi dan kredibilitas di mata masyarakat (seperti artis, tokoh politik, tokoh agama, dan sebagainya). Pada kasus-kasus yang telah diidentifikasi, modus-modus penawaran ini yang menyebabkan banyak orang tertarik untuk menyetorkan atau menanamkan dananya pada kegiatan usaha pelaku. Karakteristik penghimpunan atau penarikan sejumlah dana besar dari masyarakat (sejumlah besar orang) ini menjadi penyebab utama suatu kejahatan penipuan berada dalam skala masif.

Kelima, pengelolaan keuangan korporasi yang tidak profesional dan transparan. Pengelolaan keuangan korporasi dibawah kendali penuh pemilik dan pengurus korporasi serta kroni-kroninya, tanpa pengawasan dan manajemen kontrol dari pihak independen lainnya. Pemilik korporasi dengan bebas dapat mengakomodir kepentingan-kepentinganya melalui instrumen keuangan serta aliran atau transaksi keuangan korporasi. Menurut teori fraud triagle model beserta pengembangannya22,

21 Carey, C., \& Webb, J.K. (2017). Ponzi Schemes and the Roles of Trust Creation and Maintenance. Journal of Financial Crime, 24 (4): 589-600, DOI: https://doi.org/10.1108/JFC-062016-0042, h. 596-599.

U.S. Securities and Exchange Comission, "Ponzi Schemes," 2013, https://www.sec.gov/fastanswers/ answersponzihtm.html., diakses 20 November 2019

22 Fraud triangle model didasarkan pada studi Donald Cressey (1953) tentang 3 elemen terjadinya penipuan, yakni pressure (tekanan keuangan maupun non keuangan seperti hutang, sikap tamak, harga diri), opportunity (peluang sekitar seperti tata kelola korporasi dan kontrol yang lemah), rationalization (pemikiran rasional, seperti keberhasilan penipuan yang dilakukan sebelumnya). Model ini kemudian berkembang di antaranya Diamond Model (model ini 
keadaan demikian merupakan elemen peluang (opportunity) dari alasan terjadinya kecurangan. Ditambah elemen kebiasaan tidak etis seseorang (sikap tamak, hasrat pengakuan sosial) serta pemikiran rasionalnya ${ }^{23}$, maka pemilik korporasi dapat dengan mudah melakukan berbagai penyimpangan dan perbuatan curang yang berujung pada kejahatan, mulai dari pembohongan kegiatan usaha korporasi, manipulasi atas transaksi dan laporan keuangan hingga penggelapan dana untuk kepentingan pribadi.

Keenam, adanya transaksi keuangan yang kompleks. Penghimpunan atau penarikan dana-dana dalam jumlah besar dari banyak pihak, maka berimplikasi pula pada banyaknya transaksi-transaksi keuangan yang dilakukan para pihak. Transaksi yang banyak ini kemudian bercampur dengan transaksi-transaksi untuk kepenting pribadi pendiri atau pengendali korporasi, termasuk juga transaksi-transaksi dengan tujuan kecurangan atau manipulasi yang dilakukan oleh para pelaku., yang pada akhirnya menciptakan rangkaian tranksaksi-transaksi yang kompleks.

Ketujuh, perbuatan para pelaku dilakukan dalam tempus yang relatif lama. Para pelaku bertanggungjawab atas rangkaian perbuatan kompleks yang masing-masing tidak bisa dipandang berdiri sendiri atau memiliki hubungan sedemikian rupa yang saling berlanjut, mulai dari pendirian korporasi, melakukan berbagai penawaran, membentuk skema perjanjian, penghimpunan atau penarikan dana dari masyarakat, hingga penyimpangan dan manipulasi atas dana-dana yang diperoleh dari masyarakat. Oleh karena merupakan rangkaian perbuatan, terdapat kurun waktu yang relatif lama, bahkan bertahun-tahun untuk menjadikan suatu penipuan berada dalam skala masif.

Kedelapan, kompleksitas pelanggaran peraturan perundang-undangan. Kompleksitas rangkaian perbuatan yang dilakukan pelaku juga berimplikasi logis pada pelanggaran peraturan perundang-undangan yang ada. Pada kasus-kasus yang telah diidentifikasi, para pelaku tidak dibatasi pelanggarannya hanya menurut ketentuan penipuan atau penggelapan kovensional dalam Kitab Undang-Undang Hukum Pidana (KUHP) saja, melainkan juga berbagai ketentuan-ketentuan pidana dalam peraturan perundangundangan Indonesia yang sifatnya lex specialis derogat lege generali ataupun lex specialis sistematis, seperti kejahatan perbankan, kejahatan pencucian uang dan sebagainya. Tidak hanya berhenti pada ketentua pidana saja, rangkaian perbuatan pelaku secara nyata juga melanggar beberapa peraturan administratif yang ditetapkan pemerintah, misalnya peraturan di bidang perbankan, investasi atau koperasi pada kasus Cipaganti dan Pandawa, serta pada kasus GTI Syariah hingga peraturan kementerian Agama pada kasus First Travel dan Abu Tours.

Sekalipun melanggar berbagai ketentuan hukum, perbuatan pelaku tersebut tetap harus dipahami hakikatnya sebagai kejahatan penipuan, bukan semata-mata karena memenuhi rumusan delik penipuan menurut KUHP, tetapi karena perbuatanperbuatan tersebut pasti berpokok pada kehendak jahat (mens rea) untuk memperoleh

memasukkan elemen kemampuan dan keterampilan pelaku) atau Meta Model Framework (model yang lebih komplek dengan banyak elemen seperti karakter individu, integritas, ketermapilan pelaku, hingga anti fraud control dan sebagainya). Bekiaris, M., \& Papachristou, G. (2017).Corporate and Accounting Fraud: Types, Causes and Fraudster's Business Profile. Corporate Ownership and Control, 15 (1): 467-475, DOI: 10.22495/cocv15i1c2p15, h. 468-469.

23 Ibid. 
keuntungan atau hak-hak yang secara hukum milik orang lain serta tindakan jahat (actus reus) berupa penyiasatan atas kebenaran atau menggunakan tipu muslihat apapun bentuknya (kebohongan, pemalsuan, tipu daya).

\subsection{Problematika Korban dan Sistem Pemulihan Integratif atas Kerugian Korban Penipuan Masif}

Kasus-kasus penipuan skala masif dengan berbagai karakteristik khususnya yang terjadi di Indonesia tersebut pada gilirannya pasti menimbulkan problematika penegakan hukum yang kompleks, utamanya pada upaya-upaya pemulihan atas kerugian-kerugian yang diderita para korban. Pada sistem peradilan pidana yang berorientasi pada perlindungan hak-hak korban, pemulihan kerugian korban diwujudkan dalam konsep restitusi dan kompensasi. Kedua konsep ini pada dasarnya mengandung makna yang sama yakni pemulihan kerugian, kerusakan atau penderitaan yang diberikan kepada korban sebagai akibat dari kejahatan. ${ }^{24}$

Pemulihan yang yang dimaksud dapat meliputi berbagai hal, mulai dari pengembalian harta kekayaan atau pembayaran uang atas kehilangan harta kekayaan korban, penggantian biaya yang dikeluarkan korban termasuk biaya perawatan medis dan pemulihan psikologis, atau bahkan penggantian kerugian-kerugian yang mungkin ditimbulkan di masa mendatang (seperti kerugian korban yang secara fisik tidak mampu lagi bekerja sehingga tidak dapat memperoleh penghasilan). ${ }^{25}$ Perbedaan keduanya hanya terletak pada pihak yang melakukan pemulihan. ${ }^{26}$ Pada restitusi, tindakan pemulihan dilakukan oleh pelaku kejahatan atau pihak ketiga sedangkan kompensasi dilakukan oleh negara didasarkan pada pertimbangan-pertimbangan tertentu seperti karena restitusi dari pihak pelaku tidak sepenuhnya dapat dilakukan atau juga berdasarkan jenis kejahatan yang dilakukan. ${ }^{27}$

Di Indonesia, proses hukum atas restitusi dan kompensasi didasarkan pada UndangUndang No. 13 Tahun 2006 tentang Perlindungan Saksi dan Korban jo. Undang-Undang No. 31 Tahun 2014 tentang Perubahan atas Undang-Undang Nomor 13 Tahun 2006 (selanjutnya UU Perlindungan Saksi dan Korban) beserta peraturan-peraturan pelaksananya. Proses hukum restitusi dan kompensasi menurut peraturan tersebut sama-sama harus berdasarkan permohonan korban untuk selanjutnya ditetapkan dalam putusan atau penetapan pengadilan yang berwenang, hanya saja untuk proses hukum atas kompensasi khusus ditujukan pada pengadilan hak asasi manusia, atau korban tindak pidana berupa pelanggaran hak asasi manusia yang berat, bukan untuk setiap korban tindak pidana.

24 Boland, M, op.cit., h. 9-10, 87-88.

25 The Victims of Crime Resource Center (VLRC). (2015). A Victim's Guide to Restitution Sacramento: University of the Pasific McGeorge School of Law, h. 5.

26 Samudra, A.H. (2019). Redressing The Online Transaction Fraud Victim Treatment and Interest Fulfillment in Criminal Justice System. Jurnal Hukum dan Pembangunan 49 (3): 650660, DOI: http://dx.doi.org/10.21143/ihp.vol49.no3.2192, h. 652-653.

27 Dussich, J.P.J. (2006).Victimology-Past, Present, and Future. 131 $1^{\text {st }}$ International Senior Seminar Visiting Experts' Papers, h. 2-3. 
Oleh karena itu dalam konteks hukum positif Indonesia pemulihan kerugian bagi korban kejahatan penipuan skala masif tidak bisa dilakukan dalam bentuk kompensasi. Proses hukum atas restitusi dan kompensasi secara normatif dan faktual tidak berjalan sendiri sebagai upaya korban memulihkan kerugian yang dideritanya. Ketentuan hukum positif Indonesia mengatur beragam upaya hukum yang dapat ditempuh korban (termasuk para korban penipuan skala masif) untuk memperoleh hak-haknya baik secara langsung maupun tidak langsung. Secara lengkap, berikut dapat dijelaskan masing-masing upaya hukum tersebut:

1) Upaya gugatan ganti kerugian berdasarkan perbuatan melawan hukum atau wanprestasi.

Upaya ini dilakukan korban berdasarkan hukum acara perdata khususnya sesuai Kitab Undang-Undang Hukum Acara Perdata (HIR). Korban dapat mendudukkan pelaku sebagai pihak yang telah menimbulkan kerugian karena telah melakukan perbuatan melawan hukum menurut Pasal 1365 BW ataupun melakukan perbuatan wanprestasi berdasarkan perjanjian yang dibuat antara pelaku dan korban.

2) Upaya permintaan penggabungan perkara gugatan ganti kerugian dengan perkara pidana sesuai KUHAP.

Upaya yang dimaksud dilakukan berdasarkan hukum acara pada KUHAP, namun sekaligus didasarkan pula ketentuan Kitab Undang-Undang Hukum Acara Perdata (HIR). Pasal 98-101 KUHAP mengatur upaya permintaan dari pihak korban kejahatan untuk menggabungkan perkara gugatan ganti kerugiannya dengan perkara pidana yang sedang diperiksa di pengadilan. Pada upaya ini, KUHAP hanya menentukan jika putusan tentang ganti kerugian korban hanya menyangkut penggantian atas biaya yang telah dikeluarkan oleh korban.

3) Upaya permohonan kepailitan menurut UU Kepailitan,

Upaya permohonan kepailitan juga dapat dilakukan oleh korban sebagai bentuk kekhususan hukum acara perdata. Hubungan keperdataan antara pelaku dan korban yang berbentuk perjanjia, memuat perikatan yang dapat dikonsepsikan sebagai hutang-piutang. Dalam hal ini, pelaku kejahatan didudukkan sebagai debitur yang memiliki kewajiban untuk membayarkan sejumlah dana, kepada para korban sebagai kreditur dalam tempo tertentu, contohnya hutang piutang berupa pembayaran keuntungan investasi seperti pada kasus Koperasi Cipaganti, Pandawa atau GTI Syariah atau pengembalian biaya ibadah umrah bagi nasabah yang tidak diberangkatkan seperti pada kasus First Travel dan Abu Tour. Jika para korban mampu membangun dan membuktikan dalil tentang hutang piutang yang memenuhi syarat kepailitan, maka para korban jelas dapat mengajukan upaya permohonan kepailitan dan memperoleh ganti kerugiannya berdasarkan pemberesan hutang-hutang yang dilakukan kurator.

4) Upaya permohonan restitusi kepada pengadilan melalui Lembaga Perlindungan Saksi dan Korban (LPSK).

Upaya permohonan restitusi dilakukan korban berdasarkan UU Perlindungan Saksi dan Korban. Upaya ini secara tegas mendudukkan pemohon benar-benar sebagai korban kejahatan, tidak seperti pada upaya-upaya sebelumnya. Para korban kejahatan penipuan dalam hal ini mengajukan permohonan pada pengadilan yang memeriksa perkara pidana melalui Lembaga Perlindungan Saksi Korban sebagai lembaga negara. Upaya pengajuan permohonan restitusi dapat dilakukan sebelum maupun sesudah putusan pengadilan terkait perkara kejahatan penipuan telah memperoleh kekuatan hukum. 
Dari uraian di atas, secara normatif di Indonesia tidak ada ketentuan peraturan yang tegas dan jelas melarang apabila seorang atau sekelompok korban telah menempuh upaya yang satu, maka upaya yang lain tidak boleh dilakukan. Demikian juga tidak ada ketentuan yang mengatur upaya mana yang didahulukan apabila upaya-upaya tersebut berjalan beriringan, sekalipun secara praktik mungkin saja pengadilan atau hakim menunda upaya-upaya lain, sebelum pemeriksaan secara pidana dilakukan dan pelaku diputus bersalah. Namun, tidak semua hakim dan pengadilan akan menempuh cara yang sama, karena hal tersebut hanya didasarkan pada kebiasaan praktik hukum. Disamping itu, jika pemeriksaan secara pidana selesai dilakukan dan pelaku diputus bersalah pun, hal ini juga tidak menutup kemungkinan para korban untuk menempuh upaya hukum lainnya. Dengan demikian, terdapat kemungkinan upaya-upaya hukum pemulihan kerugian tersebut berjalan beriringan atau saling berlanjut satu sama lain. Jika hal tersebut terjadi maka timbul problematika para korban menghadapi kompleksitas ketentuan pemulihan atas kerugian sebagaimana dapat diilustrasikan pada skema berikut:

\section{Gambar 1. Ilustrasi Kemungkinan Upaya-Upaya Hukum Pemulihan Kerugian Korban Kejahatan Penipuan Skala Masif}

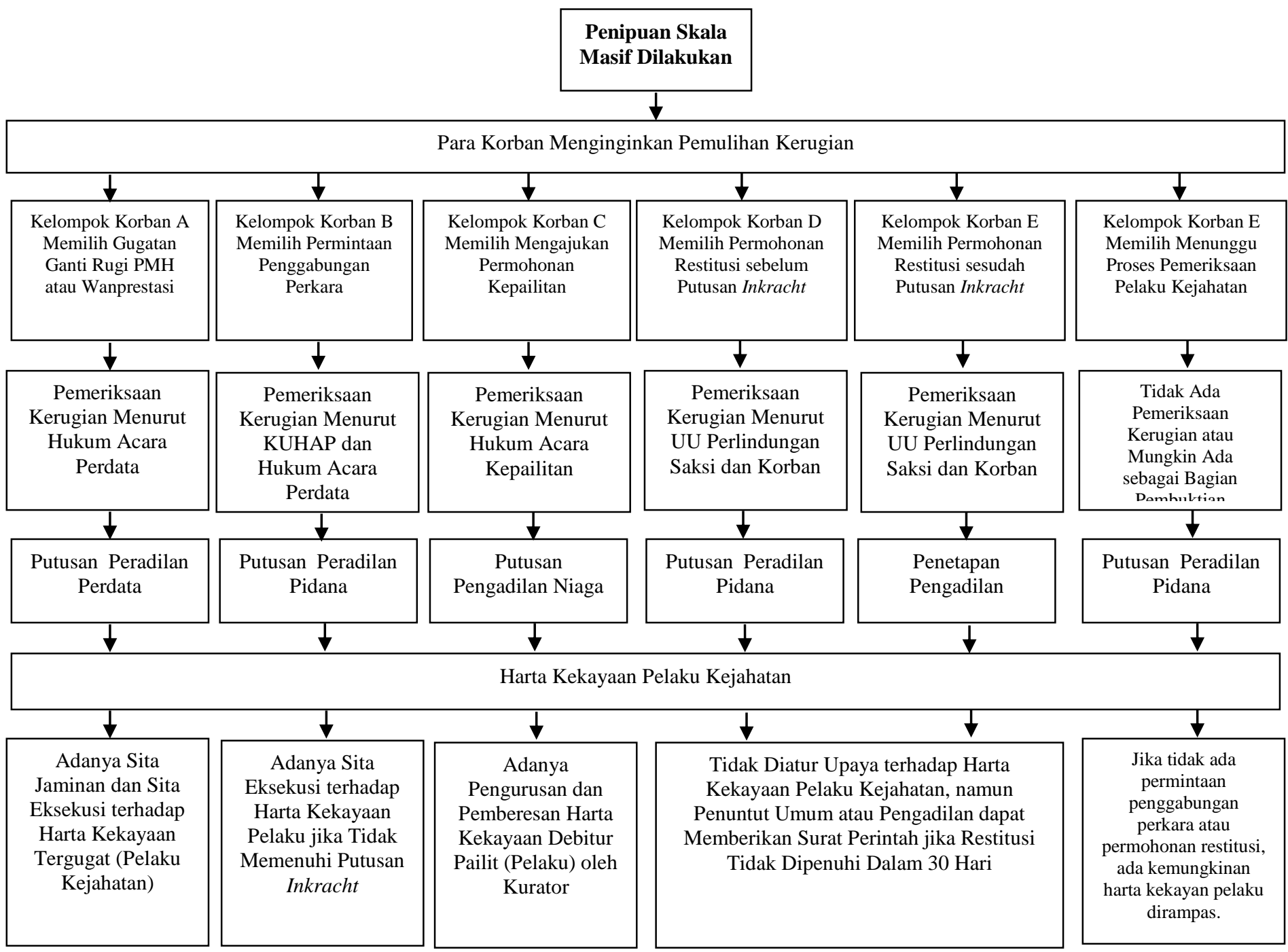


Skema ilustrasi tersebut di atas menggambarkan jelas bahwa setiap upaya hukum yang ditempuh berimplikasi pada hukum acara, produk hukum, konsekuensi atau akibat hukumnya yang berbeda-beda satu sama lain. Upaya hukum beserta implikasinya tesebut tentu juga akan berkaitan dan ditujukan terhadap harta kekayaan pelaku kejahatan, terlebih apabila pelaku kejahatan dirasa oleh para korban tidak mampu lagi memenuhi kewajibannya untuk melakukan ganti rugi. Harta kekayaan yang dimiliki atau dikuasai pelaku kejahatan tersebut tentu telah bercampur satu sama lain, dan apabila hendak dilakukan upaya hukum terkait harta kekayaan tersebut, maka terdapat sekian banyak kepentingan korban atas harta kekayaan tersebut.

Rasionalitas ini yang membawa setiap korban atau kelompok-kelomok korban penipuan skala masif memiliki probabilitas untuk menempuh tiap upaya hukum yang berbeda-beda sesuai kehendak dan pertimbangan yang menguntungkan dirinya masing-masing, baik dalam kurun waktu bersamaan atau berjalan beriringan atau berlanjut satu sama lain. Semakin banyak upaya hukum yang ditempuh oleh tiap-tiap korban, maka akan semakin banyak pula implikasi-implikasi hukum yang timbul dan saling tumpang tindih, termasuk akibat hukum atas harta kekayaan pelaku kejahatan. Dapat dibayangkan betapa rumitnya penyelesaian apabila harta kekayaan pelaku kejahatan berada dalam sita eksekusi pada beberapa upaya hukum dan kemudian sebagian atau seluruh harta lagi berada dalam pemberesan dan pengurusa kurator, atau mungkin pula sebagian justru dirampas oleh negara. Kompleksitas dan tumpang tindihnya ketentuan pemulihan atas kerugian tersebut, kemudian akan ditambah lagi dengan perhitungan ganti kerugian materiil yang jelas tidak sederhana serta distribusi dan penyerahan ganti kerugiannya untuk korban-korban yang demikian banyak. Dengan demikian, pada akhirnya pemulihan atas kerugian korban menjadi berlarutlarut serta penanganan harta kekayaan pelaku kejahatan yang terkait langsung maupun tidak dengan kejahatan, justru tidak dapat terdistribusi secara merata dan adil untuk masing-masing korban kejahatan.

Penjelasan di atas terbukti terjadi pada kasus-kasus yang telah diidentifikasi karena hingga saat ini penyelesaian pemulihan kerugian belum mampu dilaksanakan. Hal ini terjadi bahkan jauh sesudah perkara pidana atas pelaku kejahatan telah diputus berkekuatan hukum tetap oleh pengadilan. Sebagai contoh pada kasus Pandawa. Pada kasus ini terdapat dua putusan berkaitan dengan harta kekayaan pelaku yang disita. Pengadilan Negeri Depok terkait perkara pidananya memutuskan bahwa harta kekayaan pelaku dirampas Negara sedangkan Pengadilan Niaga Jakarta terkait perkara kepailitan, memutuskan bahwa harta kekayaan pelaku dibagikan kepada para kreditur (korban) yang berhak secara adil dan berimbang. ${ }^{28}$

Hal yang sama juga terjadi dalam kasus First Travel. Harta kekayaan para pelaku menurut putusan pengadilan juga dirampas untuk negara, akan tetapi disisi lain para korban juga mengajukan permohonan kepailitan pada pengadilan niaga. Sekalipun sudah ada putusan yang berkekuatan hukum tetap pada masing-masing perkara tersebut, pada kenyataannya hal ini tidak menjamin para korban untuk memperoleh pembayaran sebagai pemulihan kerugiannya secara nyata hingga saat ini. Keadaan ini

28 Andi Saputra, “Babak Baru Sengketa Aset Koperasi Pandawa Rp 3,3 Triliun," Detiknews, 2019, https://news.detik.com/berita/d-4534163/babak-baru-sengketa-aset-koperasi-pandawa-rp33-triliun, diakses 15 November 2019. 
menegaskan adanya problematika pokok dalam ruang kepastian hukum, khususnya sistem pemulihan kerugian korban. ${ }^{29}$

Untuk mengurai persoalan pokok tersebut, maka penting untuk dipahami terlebih dahulu bahwa secara etiologis (sebab-musababnya) kejahatan penipuan berhubungan erat dengan hubungan hukum keperdataan yang dibentuk antara pelaku dan korban. Kejahatan penipuan pada umumnya diliputi atau didahului dengan hubungan hukum keperdataan, terlepas apakah pelaku memiliki niat (mens rea) melakukan kejahatan atau tidak sejak awal hubungan tersebut dibangun. Pemaparan kasus dan karakteristik kejahatan penipuan skala masif telah membuktikan bahwa para pelaku kejahatan penipuan selalu memulai hubungannya dengan korban berdasarkan legitimasi hubungan hukum keperdataan, berupa perikatan dalam bentuk perjanjian tertulis, baik yang dituangkan dalam akta di bawah tangan maupun akta notariil. Salah satu konsekuensi atas hubungan ini ialah para pihak termasuk korban dapat mengupayakan saluran-saluran penyelesaian ganti kerugian seperti upaya gugatan wanprestasi atau gugatan perbuatan melawan hukum serta upaya permohonan kepailitan yang seluruhnya berada pada ranah bidang hukum keperdataan.

Upaya-upaya tersebut menjadi semakin kompleks dengan penegakan hukum pada sistem peradilan pidana itu sendiri serta sistem restitusi yang pada hakikatnya sama dengan ganti kerugian untuk korban sebagai bentuk perkembangan sistem peradilan pidana yang berorientasi pada perlindungan hak-hak korban. Masing-masing sistem tersebut tidak berhenti hanya pada pemeriksaan ganti kerugian semata, tetapi juga berlanjut pada tindakan hukum yang dikenakan terhadap harta kekayaan milik pelaku, baik yang berhubungan langsung dengan kejahatan maupun tidak, terlepas apapun nomenklatur tindakan tersebut. Oleh karena adanya perbedaan aturan dan sistem baik pada upaya ganti kerugian maupun tindakan-tindakan terhadap harta kekayaan pelaku, maka penyelesaian pertama yang harus dilakukan ialah merumuskan secara tegas sistem yang memiliki wewenang dan tugas utama untuk memulihan hak-hak korban. Perumusan sistem tidak dilakukan degan memilih sistem yang ada, apakah itu sistem peradilan perdata, pidana, kepailitan ataupun sistem restitusi, melainkan memadukan keutamaan-keutamaan atau fitur-fitur pada hukum acara masing-masing sistem yang mendukung dan memperkuat penyelesaian pemulihan kerugian yang integratif dan adil bagi korban. Perpaduan sistem tersebut dapat dirumuskan sebagai berikut.

Pertama, sistem ini menggunakan fitur peradilan pidana khususnya untuk memeriksa perbuatan dan kesalahan pelaku serta penjatuhan sanksi pidana. Secara prinsip, sebelum putusan tentang sanksi dijatuhkan dan dilaksanakan pada seseorang, maka peradilan harus menemukan terlebih dahulu kebenaran tentang perbuatan dan kesalahan orang tersebut. Prinsip peradilan ini berlaku secara universal, baik dalam peradilan pidana maupun perdata, akan tetapi kebenaran yang hendak ditemukan dalam pembuktian peradilan pidana memiliki tingkatan yang lebih tinggi dibandingkan peradilan perdata.

29 Dani Prabowo, "Aturan Yang Sebabkan Aset First Travel Disita Negara Dan Polemiknya," 2019, https://nasional.kompas.com/read/2019/11/20/11215191/aturan-yang-sebabkanaset-first-travel-disita-negara-dan-polemiknya?page=all, diakses 23 November 2019 . 
Peradilan pidana memiliki tujuan untuk memperoleh kebenaran materiil atau objective truth, yakni kebenaran hakiki yang selengkap-lengkapnya tentang suatu perkara, berbeda halnya dalam peradilan perdata yang perkaranya dapat diselesaikan hanya dengan kebenaran formil yakni kebenaran yang cukup diperoleh berdasarkan buktibukti formil yang diajukan salah satu pihak. ${ }^{30}$ Hal ini dapat dipahami demikian karena perbuatan yang diperiksa dalam peradilan pidana memiliki dimensi pelanggaran terhadap kepentingan umum (masyarakat), tidak hanya kepentingan hak pribadi seseorang. Dengan demikian, hukum pidana merupakan hukum publik. Kedudukan ini menjadi sumber legitimasi negara untuk menjatuhkan sanksi-sanksi koersif seperti perampasan kemerdekaan yang memiliki tingkat kekejaman lebih tinggi dibandingkan sanksi-sanksi pada peradilan perdata. ${ }^{31}$

Pembuktian kebenaran tentang perbuatan dan kesalahan pelaku selanjutnya menjadi ratio decidendi bagi hakim dalam menjatuhkan sanksi bagi pelaku kejahatan tersebut. Pada tataran ini, restitusi dan perampasan atas harta kekayaan pelaku kejahatan menjadi dua bentuk sanksi pidana yang dijatuhkan pada pelaku. Kedua sanksi pidana ini diterapkan sebagai alternatif satu sama lain, artinya apabila sanksi kewajiban restitusi pada korban tidak dapat dipenuhi oleh pelaku kejahatan, maka sanksi perampasan aset dijalankan untuk selanjutnya dikembalikan pada para korban penipuan sebagai pihak yang berhak (asset recovery system). ${ }^{32}$ Mengingat pula perbuatan yang dilakukan para pelaku merupakan kejahatan yang berarti melanggar kepentingan umum, maka sanksi pokok harus dijatuhkan disamping sanksi restitusi dan perampasan harta kekayaan yang didudukkan sebagai sanksi pidana tambahan.

Kedua, sistem pemulihan ini juga menggunakan fitur peradilan perdata untuk melakukan pemeriksaan terhadap kerugian para korban kejahatan penipuan skala masif. Apabila para pelaku didakwa dengan pasal kejahatan tertentu, maka unsur perbuatan pada kejahatan tersebut belum tentu meliputi unsur kerugian para korban, sehingga belum tentu pula kerugian para korban ini diperiksa, dibuktikan, atau diperhitungkan secara rinci. Oleh karena itu, fitur peradilan perdata yang menghendaki pemeriksaan dan pembuktian unsur kerugian harus digunakan. Pada perkara perdata, pemeriksaan dan pembuktian kerugian digunakan sebagai ratio legis paling konkret dalam mewujudkan pertanggungjawaban pihak tergugat, untuk selanjutnya ditetapkan oleh suatu putusan condemnatoir atau putusan yang menghukum pihak tergugat untuk melaksanakan ganti kerugian. ${ }^{33}$ Sejalan dengan hal tersebut, maka sanksi restitusi yang hakikatnya merupakan bentuk ganti kerugian juga membutuhkan pemeriksaan serta

30 Pedoman Pelaksanaan KUHAP 1982.

Muhaimin. (2016). Keberadaan Hakim Komisaris Dan Transparansi Dalam Proses Penyidikan. Jurnal Penelitian Hukum De Jure, 16 (2): 215-230, DOI: http://dx.doi.org/10.30641/dejure.2016.V16.215-230, h. 228-230.

31 Thorburn, M.B. (2011). Criminal Law as Public Law. dalam Duff R.A \& Green, S.P. (2011), The Philosophical Foundations of Criminal Law. Oxford: Oxford University Press, h. 23-24.

32 Jean-Pierre Brun et al. (2011). Asset Recovery Handbook, A Guide for Practitioners. Washington D C: The International Bank for Reconstruction and Development/The World Bank, h. 119-120. Section Money Laundering and Asset Recovery, Criminal Division, U.S Department of Justice (2019). Asset Forfeiture Policy Manual. Whasington, D.C.: Justice, U.S. Department of Division Criminal, h. 180-182.

33 Harahap, Y. (2016). Hukum Acara Perdata Tentang Gugatan, Persidangan, Penyitaan, Pembuktian, Dan Putusan Pengadilan. Jakarta: Sinar Grafika, h. 877. 
pembuktian secara nyata dan terperinci terhadap kerugian-kerugian para korban kejahatan, bukan sebatas pembuktian unsur pasal kejahatan tentanga ada atau tidaknya kerugian. Oleh karena itu, pemeriksaan dan pembuktian kerugian sebagai fitur peradilan perdata dalam sistem pemulihan ini dilakukan untuk menjawab persoalanpersoalan tentang siapa saja korban yang mengalami kerugian dan berapa jumlah pasti kerugian tiap korban dalam kasus penipuan skala masif.

Ketiga, sistem pemulihan kerugian juga membutuhkan fitur peradilan kepailitan, khususnya terkait forum distribusi harta kekayaan pelaku kepada korban. Peradilan kepailitan merupakan bentuk khusus dari peradilan keperdataan yang menangani persoalan hutang piutang, keadaan pailit dari debitur dan bagaimana pembagian harta kekayaan debitur pailit tersebut (debt pooling). Peradilan kepailitan dalam UU Kepailitan menggunakan cara sita umum atas seluruh harta kekayaan debitur yang dinyatakan pailit dan selanjutnya melakukan pemberesan atas harta kekayaan tersebut sebagai pembayaran atas hutang-hutang kepada para kreditur berdasarkan prinsip-prinsip tertentu. Kurator dalam hal ini yang akan bertugas melakukan pengurusan dan pemberesan harta kekayaan pailit dengan pengawasan dari hakim. ${ }^{34}$

Prinsip-prinsip yang digunakan dalam pemberesan kepailitan di antaranya prinsip paritas creditorium, prinsip pari pasu pro rata parte dan prinsip stuctured pro rata. Prinsip paritas creditorium berarti segenap harta kekayaan dari debitur (baik bergerak dan tidak bergerak maupun yang telah nyata dimiliki atau yang pasti dimiliki di kemudian hari) menjadi jaminan umum atas segala perikatan hutang-hutang yang dibuatnya, sehingga setiap kreditur memiliki hak yang setara atas harta kekayaan debitur jika debitur tidak dapat membayar hutang-hutangnya. ${ }^{35}$ Prinsip tersebut kemudian dilengkapi dengan prinsip pari pasu pro rata parte yang berarti harta kekayaan debitur yang menjadi jaminan para kreditur tersebut mesti dibagi secara proporsional sesuai dengan besar tagihannya, kecuali yang menurut peraturan perundang-undangan ditentukan sebagai kreditur yang harus didahulukan. Dengan demikian, maka kreditur yang memiliki piutang lebih besar akan mendapat pembayaran yang lebih besar pula dibandingkan dengan kreditur yang memiliki piutang lebih kecil. ${ }^{36}$ Selanjutnya, demi keadilan kedua prinsip tersebut juga dilanjutkan dengan prinsip stuctured pro rata atau structured creditor yang berarti pembayaran hutang-hutang dilakukan dengan mengklasifikasikan atau menggolongkan berdasarkan kedudukan masing-masing kreditur tersebut. Pembagian ini tidak lagi memperhatikan porsi besar kecilnya hutang tetapi hak preferensi kreditur

34 Pasal 16 dan Penjelasannya dalam Undang-Undang No. 37 Tahun 2004 Tentang Kepailitan Dan Penundaan Kewajiban Pembayaran Utang).

35 Prinsip ini diatur dalam Pasal 1131 Staatsblaad Nomor 23 Tahun 1847 Tentang Burgerlijk Wetboek Voor Indonesie (Kitab Undang-Undang Hukum Perdata) serta tercermin pada Pasal 1 ayat (1), Pasal 2 ayat (1) dan Pasal 21 Undang-Undang No. 37 Tahun 2004 Tentang Kepailitan Dan Penundaan Kewajiban Pembayaran Utang (Republik Indonesia, 2004).

Subhan, M.H. (2008). Hukum Kepailitan: Prinsip, Norma, Dan Praktik Di Peradilan. Jakarta: Kencana Prenada Media, h. 27-28.

36 Prinsip ini diatur dalam Pasal 1132 Staatsblaad Nomor 23 Tahun 1847 Tentang Burgerlijk Wetboek Voor Indonesie (Kitab Undang-Undang Hukum Perdata), dan tercermin pada Pasal 176 huruf a dan Pasal 189 ayat (4) dan ayat (5) Undang-Undang No. 37 Tahun 2004 Tentang Kepailitan Dan Penundaan Kewajiban Pembayaran Utang.

M. Hadi Subhan, op.cit., h. 30. 
yang ditentukan perundang-undangan. ${ }^{37}$ Penggolongan sesuai prinsip ini melahirkan tiga jenis kreditur yakni kreditur separatis, kreditur preferen dan kreditur konkuren. Sistem pemulihan kerugian korban kejahatan penipuan skala masif dapat menggunakan fitur yang serupa dengan cara dan prinsip peradilan kepailitan tersebut. Sanksi perampasan harta kekayaan pelaku yang dijatuhkan menjadi bentuk jaminan umum bagi para korban sesuai prinsip paritas creditorium karena sanksi kewajiban restitusi yang tidak dapat dipenuhi oleh pelaku. Apabila sanksi kewajiban restitusi benar-benar tidak dapat dipenuhi oleh pelaku dalam jangka waktu tertentu, maka sanksi perampasan harta kekayaan yang dijatuhkan harus diikuti sistem pengembalian harta kekayaan pelaku kejahatan kepada korban (asset recovery system).

Sistem pengembalian harta kekayaan ini selanjutnya diselenggarakan dengan cara-cara pengurusan dan pemberesan seperti yang dilakukan kurator pada peradilan kepailitan. Pengurusan berarti pengelolaan atas harta kekayaan pelaku tersebut, mulai dari pencatatan dan pembukuan harta kekayan tersebut, sedangkan pemberesan berarti penguangan harta kekayaan pelaku dan pembagian serta pembayarannya pada para korban. Pembayaran yang dilakukan ini kemudian mengacu pada prinsip-prinsip dalam kepailitan demi keadilan di antara para korban, yakni prinsip pari pasu pro rata parte, yang berarti pembayaran dari penguangan harta kekayaan pelaku kejahatan dilakukan secara proporsional sesuai dengan porsi kerugian yang dialami masingmasing korban. Jika dikaitkan dengan prinsip stuctured pro rata atau structured creditor dalam kepailitan, maka ada klasifikasi korban yang harus disusun dengan pertimbangan khusus sesuai dengan kedudukan korban-korban yang dimaksud.

Keempat, sistem pemulihan kerugian korban kejahatan penipuan skala masif juga perlu memadukan dengan fitur pada sistem restitusi menurut ketentuan perlindungan saksi dan korban. Pada ketentuan perlindungan saksi dan korban di Indonesia, sistem restitutsi difasilitasi oleh suatu lembaga, yakni lembaga perlindungan saksi dan korban. Lembaga ini menurut ketentuan di Indonesia memiliki tugas dan kewenangan untuk menjamin serta memberikan perlindungan dan hak-hak kepada saksi dan korban kejahatan, termasuk di dalamnya merupakan hak meperoleh restitusi. Para sistem peradilan yang berorientasi pada kepentingan korban, lembaga yang demikian tentu penting, mengingat korban kejahatan selalu berada pada posisi rentan karena viktimisasi yang terjadi, dan para korban umumnya adalah orang yang awam terhadap hukum, artinya korban merupakan orang-orang yang tidak mengetahui dan memahami prosedur-prosedur serta upaya hukum yang harus dilakukan dalam memenuhi hakhaknya. ${ }^{38}$

Pada sistem pemulihan kerugian korban kejahatan penipuan skala masif, maka lembaga yang demikian jelas dapat membantu, medampingi dan membimbing para korban dan saksi kejahatan dalam melakukan upaya-upaya hukum hingga pemenuhan hak-haknya terlaksana. Lembaga ini dapat membantu mengadvokasi perhitungan kerugian masing-

37 Sjahdeini, S.R. (2009). Hukum Kepailitan: Memahami UU No. 37 Tahun 2004 Tentang Kepailitan Jakarta: Pustaka Utama Grafiti, h. 280.

38 Wibowo, A.P.S \& Windari, R. (2019) The Role of Victim and Witnesses Protection Agency in Achieving Sustainable Development Goals: The Best Practice of Indonesia. Proceedings of the 2nd International Conference on Indonesian Legal Studies (ICILS 2019). France: Atlantis Press, 2019), 166-174, https://www.atlantis-press.com/article/125922720. 
masing korban, hingga mengawasi jalannya pemeriksaan tentang kerugian korban hingga pengurusan serta pemberesannya pada para korban. Dari berbagai fitur-fitur tersebut, maka sistem yang menjadi pelaksanaan ganti kerugian yang terintergrasi ini harus pula ditegaskan sebagai upaya pertama yang akan mendelegimitasi atau menunda upaya-upaya hukum lainnya yang dilakukan oleh para korban. Artinya tidak bisa, para korban atau pihak-pihak lainnya mengajukan upaya-upaya hukum baik terhadap pelaku ataupun harta kekayaan pelaku sebelum sistem ini telah diselesaikan. Konsep perpaduan fitur sebagaiman telah diuraikan tersebut dapat digambarkan dalam satu skema sebagai berikut:

\section{Gambar 2. Konsep Sistem Pemlihan Integratif Bagi Korban Penipuan Skala Masif}

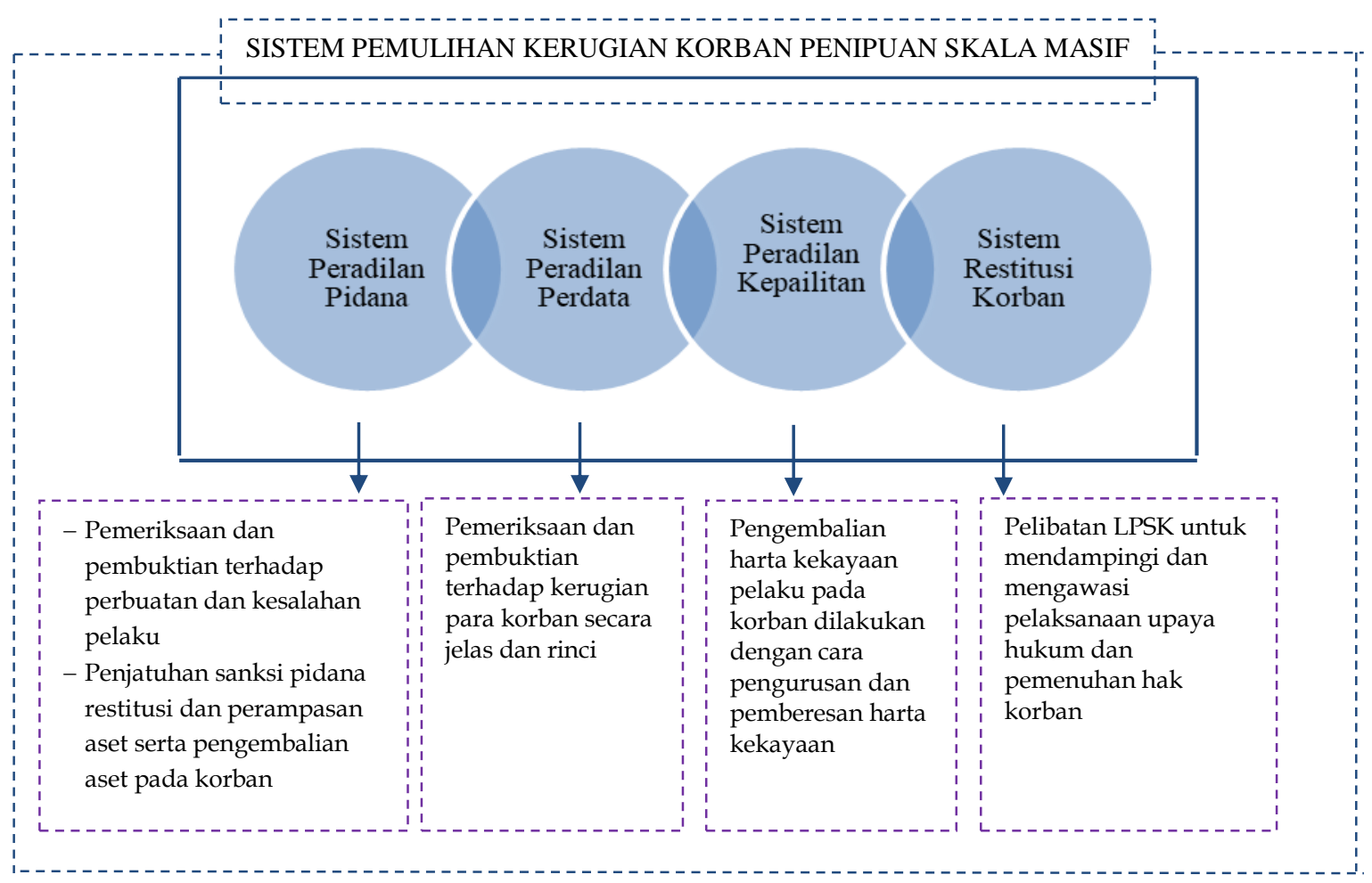

Pelaksanaan secara teknis sistem pemulihan kerugian korban kejahatan penipuan skala masif yang memadukan fitur-fitur sebagaimana telah dijelaskan dapat merujuk pada sistem yang telah diterapkan di beberapa negara. Di Amerika Serikat, sistem pemulihan kerugian korban kejahatan, salah satunya diatur dalam 28 Code of Federal Regulation (C.F.R) Part 9. Berdasarkan peraturan tersebut, terdapat dua cara untuk memulihkan kerugian korban kejahatan. Cara pertama dilakukan dengan perintah restitusi dari pengadilan berdasarkan putusan pemidanaan untuk pelaku, yang dilanjutkan dengan upaya restorasi atas harta kekayaan/ aset pelaku yang disita. Menurut cara pertama ini, kejaksaan dalam suatu kasus (USAO/United State Attorney's Office) bekerjasama dengan badan investigasi untuk mengidentifikasi korban-korban dan menentukan secara rinci kerugiannya masing-masing agar dimasukkan menjadi bagian dari perintah restitusi pengadilan. ${ }^{39}$

39 Section Money Laundering and Asset Recovery, Op.cit., h. 179-189. 
Para korban tidak perlu membuat permohonan ataupun petisi dalam upaya ini, melainkan diharuskan menyampaikan informasi-informasi terkait fakta yang diperlukan kepada badan investigasi sebelum hukuman dijatuhkan. Berdasarkan hasil identifikasi atau pemeriksaan tersebut, kejaksaan membuat dan menyerahkan permohonan restorasi, termasuk berbagai persyaratannya di antaranya informasi tertulis bahwa seluruh korban telah menerima pemberitahuan (notification) dengan jelas mengenai proses-proses restitusi dan secara layak telah diperhitungkan dalam perintah restitusi pengadilan. Persyaratan ini ditujukan untuk memastikan tidak ada satupun korban yang dilewatkan dan setiap korban telah diperlakukan secara adil. Permohonan ini ditujukan pada seksi Pencucian Uang dan Pemulihan Aset (Money Laundering and Asset Recovery Section/ MLARS yang telah menerima delegasi kewenangan oleh Jaksa Agung Amerika Serikat. Seksi MLARS kemudian memeriksa permohonan restorasi dan memberikan putusan terkait permohonoan tersebut. Jika permohonan diterima, maka Seksi MLARS akan menyampaikan pemberitahuan pada kejaksaan dan lembaga penampung aset. Lembaga penampungan aset hasil perampasan (custodian of the forfeited asset) kemudian menyerahkan seluruh harta kekayaan pelaku yang dirampas terkait suatu kasus kepada panitera pengadilan. Selanjutnya, panitera pengadilan mendistribusikan harta kekayaan hasil perampasan pelaku secara bersih kepada para korban sesuai dengan perintah restitusi pengadilan. ${ }^{40}$

Cara kedua dilakukan dengan petisi atau permintaan remisi oleh para korban. Cara ini tidak memerlukan putusan pemidanaan atau perintah restitusi terlebih dahulu pada pelaku, hanya perlu perampasan aset yang berhubungan dengan kerugian para korban. Perampasan aset yang dimaksud ini tentu dilakukan dalam bentuk perampasan aset tanpa pemidanaan (civil forfeiture atau administrative forfeiture). Menurut cara ini, kejaksaan dalam suatu kasus bekerjasama dengan badan investigasi untuk menyampaikan pemberitahuan kepada seluruh korban. Para korban selanjutnya menyusun petisi remisi untuk memperoleh kompensasi dan Kejaksaan meminta badan investigasi agar mempersiapkan laporan dan rekomendasi, untuk selanjutnya menyusun suatu rekomendasi utuh. Rekomendasi ini dikirimkan ke seksi MLARS bersama dengan petisi-petisi para korban. Seksi MLARS selanjutnya menetapkan putusan atas petisi remisi yang ditujukan untuk harta kekayan yang dirampasan secara litigasi, sedangkan penyitaan menetapkan putusan atas petisi remisi yang ditujukan untuk harta kekayan yang dirampas secara adminsitratif. Berdasarkan putusan tersebut, lembaga penampungan aset (custodian of the forfeited asset) hasil perampasan mendistrisbusikan harta kekayaan hasil perampasan pelaku secara bersih kepada para korban. ${ }^{41}$

Di Perancis, sistem pemulihan kerugian korban diatur dalam Code of Criminal Procedure, khususnya Pasal 706-3 hingga Pasal 706-15 dan Pasal R50-1 hingga Pasal R50-28. Sistem pemulihan ini melibatkan beberapa institusi di antaranya pengadilan yang memutus pelanggaran atau kejahatan, institusi yang mengelola dan memberikan dana jaminan untuk kompensasi korban kejahatan serta institusi yang memeriksa dan memutus permohonan kompensasi korban kejahatan. Negara Prancis mengambil peran dalam pemulihan kerugian korban, dengan menyediakan dana jaminan dari negara (Guarantee Fund) yang didasarkan atas solidaritas masyarakat Perancis. Ada beberapa institusi

40 Ibid.

${ }^{41}$ Ibid. 
yang mengelola dana ini yakni FGAO (Le Fonds de Garantie des Assurances Obligatoires de Dommages), yang berhubungan dengan dana kompensasi terhadap kerugian yang disebabkan oleh kecelakaan lalu lintas, bencana teknis, aktivitas pertambangan, dan pertanggungjawaban perusahaan, dan yang kedua adalah FGTI (Le Fonds de Garantie des victimes des actes de Terrorisme et d'autres Infractions) yang berhubungan dengan dana kompensasi terhadap korban terorisme, kejahatan lainnya, serta kerusakan pada kendaraan, dalam kondisi tertentu. Selain itu, ada pula korban kejahatan juga dapat memperoleh dana kompensasi dari SARVI (Service d'Aide au Recouvrement des Victimes d'Infractions) yang merupakan cabang dari FGTI. Terkait institusi yang memeriksan dan memutuskan permohonan kompensasi korban, maka terdapat lembaga bernama CIVI (Commission d'Indemnisation des Victimes d'Infractions). CIVI merupakan lembaga yudisiil yang dikepalai oleh seorang hakim yang memutus permohonan setelah mendengarkan para pihak baik korban maupun institusi pemberi dana jaminan. Saat pengadilan negeri menjatuhkan putusan pada terdakwa untuk membayar ganti rugi pada pihak yang dirugikan, pengadilan pun juga menyampaikan pada korban berkenaan dengan kesempatannya untuk menyerahkan kasus kepada CIVI. ${ }^{42}$

Beberapa persyaratan harus dipenuni pemohon dalam hal ini di antaranya, korban haruslah merupakan orang berkewarganegaraan Perancis atau berkewarganegaraan negara lain anggota Uni Eropa, juga warga negara asing yang berada di dalam wilayah Perancis secara tidak melawan hukum pada waktu terjadinya peristiwa, tetapi mengenai hal ini, peristiwa tersebut harus dilakukan di wilayah teritori Perancis. Korban harus menyerahkannya kepada CIVI dalam kurun waktu tiga tahun setelah peristiwa, satu tahun setelah putusan pengadilan. Namun, CIVI dapat menerima permohonan yang terlambat untuk kasus-kasus tertentu. ${ }^{43}$

Selanjutnya, korban mengajukan permohonan bersama seluruh kelengkapannya kepada CIVI. Klaim kompensasi tersebut akan dikirim oleh kantor CIVI ke FGTI. Proses kemudian akan diambil alih oleh FGTI. FGTI harus memberikan penawaran kompensasi dalam kurun waktu dua bulan setelah diterimanya permohonan. Penawaran ini termasuk evaluasi terhadap seluruh klaim dan nominal kompensasi yang ditawarkan. Dalam dua bulan, korban memiliki dua pilihan, yakni menerima penawaran FGTI, atau menolak penawaran FGTI. Saat insitusi pemberi uang jaminan menolak klaim, atau saat korban menolak penawaran yang dibuat untuknya, investigasi terhadap kasus akan dilakukan oleh presiden CIVI atau asisten hakim. CIVI mungkin akan membutuhkan salinan dari catatan resmi mengenai proses persidangan, walaupun proses persidangan tersebut masih sedang berjalan. Putusan dapat ditetapkan, bahkan ketika proses penuntutan masih berlangsung. ${ }^{44}$

Saat putusan pengadilan menetapkan kompensasi yang lebih besar daripada yang diberikan CIVI, korban dapat mengajukan permohonan kompensasi selebihnya dalam kurun waktu satu tahun dari putusan hakim pengadilan. Setelah keputusan dikeluarkan oleh CIVI, FGTI terikat dan harus membayar kompensasi dalam kurun waktu satu

42 The Thomson Reuters Foundation and Hogan Lovells Beijing Zhongze Women's Legal Counselling Service Centre. (2015). Compensation Schemes, Comparative Report on National State Compesation Schemes, h. 47-58.

43 Ibid.

44 Ibid. 
bulan. Korban dan FGTI dapat mengajukan banding dalam kurun waktu satu bulan. Dalam kondisi FGTI menolak atau tidak dapat memberikan kompensasi, korban masih dapat mengajukan permohonan bantuan ke SARVI dalam kurun waktu satu tahun. Korban dapat mengajukan kompensasi sementara sembari menunggu keputusan CIVI dimana hal itu tidak boleh ditolak oleh FGTI. ${ }^{45}$

Berpedoman pada 2 jenis sistem pemulihan kerugian korban yang belaku di Amerika Serikat dan Perancis, maka dapat dipahami beberapa hal pokok terkait teknis pelaksanaan sistem pemulihan kerugian korban kejahatan.

1. Ada dua cara yang dapat dirumuskan untuk mengawali proses pemulihan kerugian korban, yakni dengan permohonan dari para korban sendiri atau berdasarkan hasil pemeriksaan aparat penegak hukum yang mengharuskan adanya restitusi, perampasan aset dan pemulihan aset korban.

2. Terdapat mekanisme pemberitahuan (notifikasi) bagi para korban, notifikasi ini berisi upaya hukum yang dapat dilakukan oleh korban sendiri maupun upaya hukum yang dilakukan aparat penegak hukum berkenaan sistem pemulihan kerugian korban dalam kasus yang sedang atau telah diperiksa, termasuk juga perhitungan kerugian yang telah dilakukan oleh aparat penegak hukum.

3. Adanya institusi yang menghitung kerugian, memeriksa dan memutus permohonan pemulihan kerugian serta pengembalian aset pada korban. Institusi ini secara pasti berada dalam ruang lingkup sistem peradilan suatu negara. Di Ameriksa Serikat, institusi ini terdiri dari pengadilan dan sebuah lembaga yang menerima delegasi dari kejaksaan serta memiliki kekhususan kewenanga terkait pemulihan aset hasil kejahatan yakni MLARS. Di Prancis, proses pemeriksaan permohonan dilakukan oleh CIVI yang berada di bawah stuktur pengadilan serta lembaga yaang mengelola dana jaminan negara yakni FGTI.

4. Adanya pemeriksaan dan putusan terlebih dahulu bagi pelaku kejahatan. Putusan bagi pelaku kejahatan tersebut salah satu yang terpenting dalam hal ini adalah hukuman pidana untuk mengganti kerugian atau restitusi bagi korban.

Berdasarkan penjelasan konsep perpaduan fitur berbagai hukum acara serta beberapa hal pokok teknis sesuai perbandingan beberapa sistem maka dapat dirumuskan tahapan sistem pemulihan kerugian yang integratif bagi korban kejahatan penipuan skala masif di Indonesia sebagai berikut:

1. Tahap pertama: Permohonan Restitusi

Pada saat pemeriksan suatu kasus kejahatan penipuan dengan korban skala masif sedang dilakukan, maka para korban dapat langsung melapor atau mengajukan permohonan restitusi (ganti kerugian) pada LPSK sebagai lembaga utama yang menyediakan perlindungan dan memberikan hak atau bantuan pada korban.

2. Tahap kedua: Penyusun Permohonan Restitusi

Setelah memperoleh beberapa laporan dan permohonan restitusi, maka LPSK bekerjasama dengan penyidik untuk menyampaikan pemberitahuan (notifikasi) dan mengadvokasi korban-korban lainnya agar dalam jangka waktu tertentu segera mengajukan pula permohonan ganti kerugiannnya pada LPSK. LPSK kemudian melakukan pemeriksaan kerugian secara rinci untuk setiap korban dan menetapkan suatu permohonan restitusi mewakili seluruh korban. Permohonan ini disampaikan pada penuntut umum dalam kasus tersebut.

45 Ibid. 
3. Tahap ketiga: Dakwaan, Tuntutan dan Pemeriksan Restitusi

Penuntut umum yang menerima permohonan restitusi tersebut, kemudian memasukkannya sebagai salah satu dakwaan untuk diperiksa oleh pengadilan secara rinci. Setelah pemeriksaan dan pembuktian dilakukan, penuntut umum juga memasukkan hasil pemeriksaan kerugian sebagai bagian dari tuntutan pemidanaan. Pemeriksaan ganti kerugian korban dilakukan bersama dengan pemeriksaan perbuatan dan kesalahan pelaku dalam kasus yang bersangkutan.

4. Tahap keempat: Pemidanaan Restitusi dan Perampasan Aset

Jika benar terbukti bersalah, maka pengadilan menjatuhkan sanksi pidana pokok disertai sanksi pidana pembayaran restitusi bagi pelaku dalam jangka waktu terntentu atau sanksi pidana perampasan aset jika tidak melaksanakan sanksi pidana restitusi tersebut. apabila sanksi pidana restitusi dilaksanakan oleh pelaku maka sistem pemulihan kerugian selesai. Akan tetapi, jika sanksi pidana restitusi tidak dilaksanakan oleh pelaku dalam jangka waktu tertentu, maka sistem perampasan dan pengembalian aset pada korban dijalankan.

5. Tahap kelima: Sistem Perampasan Aset

Penuntut umum melaporkan pada pengadilan bahwa sanksi pidana restitusi tidak dapat dijalankan, sehingga pengadilan (hakim) menetapkan perintah perampasan harta kekayaan pelaku baik yang telah disita maupun belum disita dan terkait langsung maupun tidak langsung dengan kejahatan. Pengadilan selanjutnya melakukan pemeriksaan dan menetapkan distribusi atau bagian masing-masing korban atas harta kekayaan pelaku yang telah dirampas secara proporsional. Pada saat pemeriksaan atas harta kekayaan pelaku tersebut, pengadilan juga memberikan kesempatan pada pihak-pihak terkait selain korban kejahatan yang memiliki kepentingan atas harta kekayaan pelaku untuk mengajukan keberatan. Hakim selanjutnya memeriksa keberatan tersebut dan apabila diterima, maka pengadilan juga memasukkan bagian pihak-pihak tersebut dalam penetapan distribusi harta kekayaan pelaku yang telah dirampas.

6. Tahap keenam: Pemberesan Harta Kekayaan Pelaku dan Pemulihan Kerugian Korban

Penetapan distribusi harta kekayaan pelaku yang telah dirampas selanjutnya disertai dengan penunjukan pihak bertanggung jawab melakukan pemberesan. Penuntut umum yang telah ditunjuk selanjutnya melakukan invetarisir harta kekayaan pelaku dan melakukan pemberesan, termasuk dengan melelang harta kekayaan pelaku. Terakhir, penuntut umum mendistribusikan hasil lelang harta kekayaan pelaku kejahatan sesuai dengan penetapan pengadilan.

\section{Kesimpulan}

Berdasarkan pendekatan kasus, diketahui ada 8 (delapan) karakteristik dari kasus-kasus penipuan skala masif di Indonesia. Adapun ke-8 (kedelapan) karakteristik tersebut, terdiri dari: (1) memiliki dimensi kejahatan korporasi; (2) dilakukan oleh para pendiri dan pengendali korporasi; (3) adanya kegiatan penghimpunan atau penarikan sejumlah besar dana dari masyarakat; (4) adanya hubungan keperdataan yang dibentuk antara pelaku dan korban; (5) pengelolaan keuangan korporasi (kegiatan usaha) yang tidak profesional dan transparan; (6)transaksi keuangan yang kompleks (7) perbuatan para pelaku dilakukan dalam tempus yang relatif lama; (8) kompleksitas pelanggaran peraturan perundang-undangan. Kasus-kasus penipuan skala masif dengan berbagai karakteristik khususnya yang terjadi di Indonesia tersebut pada gilirannya pasti 
menimbulkan problematika penegakan hukum yang kompleks, utamanya pada upayaupaya pemulihan atas kerugian-kerugian yang diderita para korban. Kompleksitas dan tumpang tindihnya ketentuan pemulihan atas kerugian beserta implikasi hukumnya, termasuk tindakan hukum atas harta kekayaan pelaku kejahatan. Untuk menyelesaikan problematika ini, maka dapat dirumuskan suatu konsep sistem pemulihan kerugian integratif dengan memadukan keutamaan-keutamaan atau fitur-fitur pada hukum acara masing-masing sistem yang mampu mendukung dan memperkuat penyelesaian pemulihan kerugian yang adil bagi korban. Konsep sistem ini memadukan fitur-fitur dalam sistem peradilan perdata, pidana, kepailitan ataupun sistem restitusi korban itu sendiri, sehingga menghasilkan tahapan secara teknis yang terdiri atas, permohonan restitusi dam penyusun permohonan restiutusi yang melibatkan LPSK, pemeriksaan restitusi pada sidang pengadilan bersama dengan pemeriksaan perbuatan dan kesalahan pelaku dalam kasus yang bersangkutan, kemudian dilanjutnya dengan penjatuhan pemidanaan restitusi dan perampasan aset serta penerapan sistem perampasan aset. Terakhir, pemberesan harta kekayaan pelaku dan pembayaran kerugian sebagai pemulihan korban. Berdasarkan kesimpulan di atas, maka dirumuskan 2 (dua) saran yakni: Pertama, bagi pembentuk kebijakan, sistem pemulihan kerugian integratif bagi korban kejahatan skala masif dapat dirumuskan sebagai suatu kebijakan peraturan perundang-undangan di bidang perlindungan terhadap saksi dan korban. Mengingat kompleksitas kejahatan penipuan dengan skala masif, maka kebijakan ini juga harus didiukung dengan peraturan teknis yang rinci dan rigid dengan jangka waktu tertentu. Kebijakan yang demikian mencerminkan adanya kepastian hukum terhadap korban kejahatan dan menghindarkan korban dari penderitaan sekunder akibat sistem hukum yang memakan waktu lama atau bahkan tidak dapat memulihkan kerugian korban. Kedua, bagi aparat penegak hukum, sistem pemulihan kerugian integratif membutuhkan pemahaman, dan kerjasama yang sinergis serta selaras antar institusi, baik itu LPSK, Kepolisian, Kejaksaan hingga Pengadilan. Hal ini jelas berdampak pada efisiensi kinerja sistem peradilan, mulai dari identifikasi korban dan kerugiannya hingga pada tahap pembayaran kerugian korban.

\section{Daftar Pustaka/Daftar Referensi}

\section{$\underline{\text { Buku }}$}

Dignan, J. (2005). Understanding Victims and Restorative Justice. New York: Open University Press.

Boland, M. L. (2008). Crime Victim's Guide to Justice. Nappervile: Sphinx Publishing.

Subhan, M. H. (2008). Hukum Kepailitan: Prinsip, Norma, Dan Praktik Di Peradilan. Jakarta: Kencana Prenada Media.

Sjahdeini, S. R. (2009). Hukum Kepailitan: Memahami UU No. 37 Tahun 2004 Tentang Kepailitan. Jakarta: Pustaka Utama Grafiti.

Duff, R.A., \& Green, S.P. (2011) The Philosopial Foundation of Criminal Law. Oxford: Oxford University Press.

Brun, J.P., Larissa, G., Scott, C., \& Stephenson, K.M. (2011). Asset Recovery Handbook, A Guide for Practitioners. Washington D C: the International Bank for Reconstruction and Development/ The World Bank.

Harahap, Y. (2016). Hukum Acara Perdata Tentang Gugatan, Persidangan, Penyitaan, Pembuktian, Dan Putusan Pengadilan. Jakarta: Sinar Grafika. 


\section{Jurnal}

Bell, R.E. (2000). Proving the Criminal Origin of Property in Money-Laundering Prosecutions. Journal of Money Laundering Control, 4 (1), 12-25, DOI: https://doi.org/10.1108/eb027258.

Gravin, M., \& Clair, S.L. (2013). Ensuring Full Restitution for Crime Victims: Polyvictims as a Case Study in Overcoming Causation Challenges. Victim Law Bulletin, National Crime Victim Law Institute, July 2013, 1-10.

Button, M., Lewis, C., \& Tapley J. (2014). Not a Victimless Crime: The Impact of Fraud on Individual Victims and Their Families. Security Journal, 27 (1), 36-54, DOI: https:// doi.org/10.1057/sj.2012.11.

Primantasari, A.A.A., \& Sarna, K. (2014). Upaya Menanggulangi Investasi Bodong. Kertha Semaya, 2(3): 108-115.

Meliala, N.C. (2015). Pendekatan Keadilan Restoratif: Upaya Melibatkan Partisipasi Korban dan Pelaku Pidana. Veritas et Justitia, 1 (1), 111-135, DOI: https:// doi.org/10.25123/vej.1419.

Muhaimin. (2016). Keberadaan Hakim Komisaris dan Transparansi Dalam Proses Penyidikan." Jurnal Penelitian Hukum De Jure, 16 (2), 215-230, DOI: http:/ / dx.doi.org/10.30641/ dejure.2016.V16.215-230.

Deason, S.R., Rajgopal, S., \& Waymire, G.B. (2015). Who gets swindled in Ponzi Schemes. SSRN Electronic Journal, 3 (1), 1-40, DOI: http:/ / dx.doi.org/10.2139/ssrn.2586490.

Gennaioli, N., Shleifer, A., \& Vishny, R. (2015). Money Doctors. The Journal of Finance. 70 (1), 91-114, DOI: https://doi.org/10.1111/jofi.12188.

Wulf, A. J. (2016). The Contribution of Empirical Research to Law. The Contribution of Empirical Research to Law. Journal Jurisprudence, 29, 2016, 29-49. DOIhttp://dx.doi.org/10.2139/ssrn.3542277.

Bekiaris, M., \& Papachristou, G. (2017). Corporate and Accounting Fraud: Types, Causes and Fraudster's Business Profile. Corporate Ownership and Control, 15 (1), 467-475, DOI: $10.22495 /$ cocv15i1c2p15.

Carey, C., \& Webb, J.K. (2017). Ponzi Schemes and the Roles of Trust Creation and Maintenance. Journal of Financial Crime, 24 (4), 589-600, DOI: https:// doi.org/10.1108/JFC-06-2016-0042.

Jerman, H. (2017). Pemulihan Aset Hasil Kejahatan Sebagai Bentuk Perlindungan Hukum Terhadap Korban Kejahatan. DiH: Jurnal Ilmu Hukum, 13 (25), 149-161, DOI: https://doi.org/10.30996/dih.v13i25.2228.

Laing, L. (2017). Secondary Victimization: Domestic Violence Survivors Navigating the Family Law System. Violence Against Women, 23 (11), https:// doi.org/10.1177/1077801216659942.

Mantulangi, N. (2017). Kajian Hukum Investasi dan Perlindungan terhadap Korban Investasi Bodong. Lex Administratum, 5 (1), 108-115.

Martin, K.D., Smith, S.S., \& Still, W (2017). Shackled to Debt: Criminal Justice Financial Obligations and the Barriers to Re-Entry They Create. New Thinking in Comunity Correction, January (4), 1-26.

Pamungkas, H.P. (2017). Analisis Kriminologis terhadap Kejahatan Penipuan dengan Modus Penggandaan Uang (Studi Kasus di Polresta Bandar Lampung). Poenale: Jurnal Bagian Hukum Pidana, 5(16). 
Ali, M., \& Wibowo, A (2018). Kompensasi Dan Restitusi Yang Berorientasi Pada Korban Tindak Pidana. Yuridika, 33

DOI: http://dx.doi.org/10.20473/ydk.v33i2.7414.

(2), 260-289

Wibowo, A.P.S., \& Windari, R (2019). The Role of Victim and Witnesses Protection Agency in Achieving Sustainable Development Goals: The Best Practice of Indonesia. Proceedings of the 2nd International Conference on Indonesian Legal Studies (ICILS 2019), 166-174. Paris, France: Atlantis Press. https://www.atlantispress.com/article/ 125922720.

Samudra, A.H. (2019). Redressing The Online Transaction Fraud Victim Treatment and Interest Fulfillment in Criminal Justice System. Jurnal Hukum dan Pembangunan, 49 (3), 650-660, DOI: http:/ /dx.doi.org/10.21143/jhp.vol49.no3.2192,.

Surahmi, M. (2019). Perlindungan Hukum bagi Korban Penipuan Investasi (Studi Kasus di Kota Palembang). Jurnal Thengkyang, 2(1), 85-104.

Brenner, L., Meyll, T., Stolper, O., \& Walter, A. (2020). Consumer Fraud Victimization and Financial Well-being. Journal of Economic Psychology, 76 (C), DOI: https:// doi.org/10.1016/j.joep.2019.102243

\section{Online/ World Wide Web}

United Nations and the Rule of Law. (2015). Environmental Law. Retrieved from https://www.un.org/ruleoflaw/thematic-areas/land-propertyenvironment/environmental-law/, diakses 6 Mei 2018.

Aitken, R. (2018). After U.S. SEC Shuts Down \$85M Ponzi Scheme, Can They Ever Be Eradicated?" Retrieved from https://www.forbes.com/ sites/rogeraitken/2018/05/04/after-u-s-sec-shuts-down-85m-ponzi-scheme-canthey-ever-be-eradicated/, diakses 12 November $2019 .$.

Birdieni, M.A.R., \& Birny. (2013). Tipu-Tipu Investasi Emas Berkedok Syariah. Retrieved from https://www.gatra.com/detail/news/25595-tipu-tipu-investasi-emasberkedok-syariah/, diakses 12 November 2019.

Darmajati, D. (2018). Trio Penipu Calon Tamu Allah Abu Tours PT SBL First Travel. Retrieved from https://news.detik.com/berita/d-3935516/trio-penipu-calontamu-allah-abu-tours-pt-sbl-first-travel, diakses 12 November 2019.

Erdianto, K. (2017). Menelusuri Aliran Dana Jemaah Dan Sisa Aset Bos First Travel." Kompas. https://nasional.kompas.com/read/2017/08/30/07132131/menelusurialiran-dana-jemaah-dan-sisa-aset-bos-first-travel?page=all, diakses 13 November 2019.

Hurst, Mike. (2018). Lamar Adams Sentenced to 20 Years in Probable Largest Ponzi Scheme in State History. https:// www.jacksonfreepress.com/news/2018/oct/30/lamar-adams-sentenced20-years-probable-largest-po/, diakses 11 November 2019.

Liputan 6. (2013). Fakta Menggelitik Dari Penipuan Investasi Emas GTI Syariah. Retrieved from https://www.liputan6.com/bisnis/read/527856/faktamenggelitik-dari-penipuan-investasi-emas-gti-syariah, diakses 11 November 2019.

Prabowo, D. (2019). Aturan Yang Sebabkan Aset First Travel Disita Negara Dan Polemiknya. Retrieved from: https://nasional.kompas.com/read/2019/11/20/11215191/aturan-yangsebabkan-aset-first-travel-disita-negara-dan-polemiknya?page=all, diakses 23 November 2019.

Saputra, A. (2019). "Babak Baru Sengketa Aset Koperasi Pandawa Rp 3,3 Triliun." 
Detiknews. 2019. https://news.detik.com/berita/d-4534163/babak-baru-sengketaaset-koperasi-pandawa-rp-33-triliun, diakses 15 November 2019.

Syle Febrina Laureno. (2019). Ini 12 Koperasi Abal-Abal Yang Bikin Buntung." Detikfinance. https:// finance.detik.com/moneter/d-, diakses November 11, 2019.

\section{Peraturan Perundang-Undangan}

Staatsblaad Nomor 23 Tahun 1847 Tentang Burgerlijk Wetboek Voor Indonesie (Kitab Undang-Undang Hukum Perdata).

Undang-Undang Nomor 8 Tahun 1981 tentang Kitab Undang-Undang Hukum Acara Pidana. Lembaran Negara Republik Indonesia Tahun 1981 Nomor 76. Tambahan Lembaran Negara Republik Indonesia Nomor 3209.

Undang-Undang No. 37 Tahun 2004 Tentang Kepailitan Dan Penundaan Kewajiban Pembayaran Utang. Lembaran Negara Republik Indonesia Tahun 2004 Nomor 131. Tambahan Lembaran Negara Republik Indonesia Nomor 4443.

Undang-Undang No. 13 Tahun 2006 tentang Perlindungan Saksi dan Korban. Lembaran Negara Republik Indonesia Tahun 2006 Nomor 64. Tambahan Lembaran Negara Republik Indonesia Nomor 4635.

Undang-Undang No. 31 Tahun 2014 tentang Perubahan atas Undang-Undang Nomor 13 Tahun 2006. Lembaran Negara Republik Indonesia Tahun 2014 Nomor 293 Tambahan Lembaran Negara Republik Indonesia Nomor 5602.

\section{Putusan Pengadilan}

Putusan Pengadilan Negeri Bandung Nomor: 198/Pid.B/2015/PN. Bdg.

Putusan Pengadilan Tinggi Bandung Nomor: 238/PID.SUS/2015/PT.Bdg.

Putusan Mahkamah Agung Republik Indonesia Nomor: 173 K/Pid.Sus/2016.

Putusan Pengadilan Negeri Depok No. 424/Pid.Sus/2017/PN.Dpk.

utusan Pengadilan Negeri Makasar No. 1235/Pid.B/2018/PN Mks.

Putusan Pengadilan Negeri Depok No. 83/Pid.B/2018/PN. Dpk.,

Putusan Pengadilan Negeri Depok No. 84/Pid.B/2018/PN. Dpk.

Putusan Pengadilan Tinggi Bandung No.195/Pid/2018/PT. Bdg.

Putusan Mahkamah Agung Indonesia No. 3096 K/Pid.Sus/2018.

Putusan Mahkamah Agung Indonesia No. 3095 K/Pid.Sus/2018.

Putusan Pengadilan Tinggi Bandung No. 37/Pid.Sus/2018/PTBdg.

Putusan Mahkamah Agung Republik Indonesia No: 1208 K/Pid.Sus/2018. 